\title{
Evaluation of Validated Herbal Medicine Formulation for Anti- Proliferative and Apoptotic Activities Used In the Tribal Medicine System
}

\author{
G. Panduranga Murthy ${ }^{1 *}$, K. B. Chandrasekhar ${ }^{2}$, D.K. Ravishankar ${ }^{3}$, \\ B.C. Leelaja ${ }^{4}$, S. Lokesh ${ }^{5}$, B. Manju ${ }^{6}$ \\ ${ }^{*}$ Department of Engineering Chemistry, Maharaja Institute of Technology Thandavapura, \\ (Visvesvaraya Technological University, Belagavi), Nanjanagud Taluk, Mysore district-571 302 (Karnataka), India \\ ${ }^{2}$ Department of Chemical Engineering and Biotechnology, Oil Technological and Pharmaceutical Research \\ Institute Jawaharlal Nehru Technological University (JNTUA), Ananthapuramu-515 002, India. \\ ${ }^{3}$ Bhoomigeetha Institute of Research and Development (BIRD) B.H. Road, Tumkur-572 102, India. \\ ${ }^{4}$ Department of Studies in Biotechnology, University of Mysore, Manasagangothri, Mysore-560006, India. \\ ${ }^{5}$ Department of Chemistry, Sri Mahadeshwara Govt. First Grade College (University of Mysore), \\ Kollegal-571 440, Chamaraja Nagara district (Karnataka), India. \\ ${ }^{6}$ Department of Engineering Chemistry, Maharaja Institute of Technology, \\ Belavadi, Srirangapatna, Mysore-590 018.
}

\begin{abstract}
The current study was carried out to appraise the Anti-proliferative activity of Herbal Medicine Formulation (HMF) comprising different components of ethno-medicinal plant drugs which are practiced by the local healers in the Tribal Medicine System (TMS). The medicine formulation was subjected for validation with the authorized Ayurvedic Medical Practitioner in order to ascertain the active resources for novel lead constituents present in the drug. In addition, the validated HMF will also facilitate the movement of indigenous practices of traditional medicines to the public domain. The analysis was made on preliminary phyto-chemicals using fractions of HMF drug which reveals the active presence and were known to demonstrate both biomedical and physiological activities. Subsequently, the analysis of Thin Layer Chromatographic confirms the presence of diversified bioactive ingredients in the different components of HMF drug which indicates the efficacy of the HMF drug. The active fractions were prepared by serial extraction with ethanol, methanol, petroleum ether and ethyl acetate respectively based on the standard protocols and tested against MCF-7 (Mammarain Cancer cells) followed by HeLa cancer cells lines in vitro and their probable mechanism of action was critically analyzed. Further, the anti-proliferative activity was evaluated with these diversified HMF drug fractions against cancer cell lines by MTT assay, Trypan Blue assay and Hoechst's staining methods respectively. The apoptotic effects was determined and correlated for its anti-cancer activity in the extracts of HMF drug. The TLC of extracts showed that, chloroform extract moved to the maximum distance of $15 \mathrm{~cm}$ followed by ethyl acetate extract with a $14.7 \mathrm{~cm}$ as retention factor. Whereas, the ethanolic extract of $H M F$ drug moved the least distance with $6.5 \mathrm{~cm}$ retention factor and aqueous extract did not show any movement on the stationary phase. The analysis for MTT assay demonstrated that, the cell viability was diminished with the increased concentration of the HMF drug. The inhibition concentration value $\left(I C_{50}\right)$ for the MTT assay at $24 \mathrm{hrs}$ was found to be $5.1 \mu \mathrm{g} / \mathrm{ml}$ and for $48 \mathrm{hrs}$ at $5.4 \mu \mathrm{g} / \mathrm{ml}$. Later, the attentiveness of HMF drug against both MCF-7 and HeLa cancer cells was instituted to appraise the anti-proliferative activity. The arresting of cell proliferation and growth of these cancerous cells was observed even in very low concentration of the HMF drug, which may be due to the presence of bio-active constituents in the medicine formulation. Subsequently, the apoptotic assays showed that, the increased fractions of HMF drug (60, 75, 80 and 95\%) induced mitochondrial depolarization in MCF cells correspondingly, at those fractions which could have triggered the apoptosis in mitochondrial pathway. Eventually, the ability of curbing and inhibition capability of the free radicals was assessed in the different fractions of HMF drug through biochemical method like, ABTS scavenging assays respectively. The result reveals; significant ABTS free radical scavenging activity of $7 \pm 0.74$ was evident in the extract. Hence, the HMF drug was found to be most effective in deactivating these Cancer Cells and justifies the tested herbal formulation, HMF being practiced by the tribal healers in their traditional medicine system. Further, the formulation needs to be evaluated for its clinical trials through the absolute purification process in order to propose the medicine as most potential anticancer herbal drug.
\end{abstract}

Key Words: Anti-proliferative activity; Apoptosis; Antioxidant activity; Ethno-medicinal plant drugs, Herbal Medicine Formula; HeLa and MCF-7 Cell lines 


\section{Introduction}

The natural products derived mainly from plants and propose a diverse sequence of active constituents which plays a key role by regulating the biological organization with these natural antioxidants. The remedy using chief constituents of herbal formulation has been significantly accomplished which can facilitate development of most desired drug by breakthrough technology for the benefit of mankind. The large interest is currently being paid by the researchers to explore most potent natural products for their interesting counterpart activities against different ailments apart from anticancer drug research (Van, 1993).

Furthermore, the implication of wide range of medicines towards management and prevention of cancer and associated ailments are explicitly derived either from indigenous or aboriginal plants contribute around $25 \%$ of its total effectiveness. It was estimated that, nearly $60-80 \%$ of the drugs approved for cancer related therapeutics are derived from plants only. This has protracted the pursuit of efficient antioxidant and anticancer agents from natural sources particularly medicinal plants which are practiced by some ethnic group (Mishra et al., 2008; Boopathy and Karthiresen, 2010). However, the investigations on lead constituents from pant drugs have been recuperated the status by means of getting superior perceptive of their biological importance such as antimicrobial, antioxidant, radical scavenging, anti-proliferative activities (Manian et al., 2008; Caamal, 2011; Gul et al., 2013).

The ethno-medicinal plants were appraised all the way through systematic screening protocols and possess an imperative position in the drug invention and many innovative drugs have been justified with respect to effectiveness of their formulations in different cultures of traditional medicine system. Even though, the beneficial aspects of both synthetic and chemo-typing profile along with molecular modeling are in the front line. Similarly, the medicinal plants remain an essential source of any new-fangled drugs, which further leads to new chemical lead constituents along with the vital role in the biological system. Therefore, bio-prospecting of antitumor drugs from natural products is escalated now and receiving outstanding interest globally due to its target specificity and have no side effects in the therapeutic strategies (Sharma et al., 2011; Sanaz et al., 2012).

Generally, cancer' is a very serious health setback and patients are confronted with undesirable side effects resulting from conventional treatments. The complementary and alternative medicines are optional choices. Some herbal or traditional formulations from oriental medicines in some parts of India were found to be evidence for anti-cancer activities such as, anti-proliferation, anti-angiogenesis and apoptosis (Van, 1993; Manian et al., 2008; Atjanasuppat et al., 2009; Al-Rashidi et al., 2011). In Karnataka, many herbal, folklore medicines, and traditional medicine formulas have been used extensively as complementary medicines without any proven evidence of their effectiveness in the biological system. Hence, after interviewing traditional or tribal medicine men in the province of Biligirirangana Hills (Chamarajanagara district of Karnataka, it was noticed practically that, an herbal formulation (pre-prepared) used to treat cancer related ailments such as, breast, lung and liver cancers was preferred in the study. This tribal herbal formulation merits investigation for the anti-proliferative activity of its crude-aqueous extracts and its each plant component of the Herbal Medicine formulation against human cancer cells (Ravishankar and Murthy, 2011).

Mammarian cancer or breast cancer is the most numerous malignancies among women are the leading cause of death due to cancer related ailments and the consequential of the metastatic development of primary stage of cell tumors are of great concern (Jemal et al., 2006). The possible exploration of plants based medicine formulations in the treatment of different diseases together with cancers is inevitable. This would be the very basis for innovations via modern medical science, as they are considered to be vast sources of new-fangled drugs (Jones et al., 2006; Kim, 2008; Aune et al., 2009; Hasan et al., 2011; Woo and Kim, 2011). The discovery and production of drugs has been dominated by the synthetic chemistry which further facilitate both target specific and non-target drugs. Therefore, the specific protocol was established to ascertain and production of the potential drugs from bioactive plants and their extracts of active fractions will create a platform to provide new and novel products for disease management via strategic treatments but, prevention is still sizeable. Besides, the antitumor area has the greatest impact by the active constituents derived from plant drugs, where drugs like vinblastine, vincristine, taxol, and camptothecin have improved the chemotherapy of some cancers in a remarkable way.

The plants based medicines are stable which have unlimited capacity to produce active constituents that in turn attract researchers in the quest for innovative, novel and active chemotherapeutics (Lampronti et al., 2003; Ravelo et al., 2004; Itharat, 2004; Jemal, 2006; Aune et al., 2009). The long-lasting search for new-fangled anticancer lead molecules in plant medicines and traditional foods is a realistic and promising strategy for its prevention (Anusha and Murthy, 2010) in the daily life. But, in accordance with this worldwide trend of cancer related ailments and increased mortality rate, the current study was undertaken to evaluate the extracts of validated Herbal Medicine Formulation (HMF) for anti-proliferative and apoptotic activities which are being practiced by Tribal healers in the Traditional Medicine System (TMS) for Cancer and related ailments. 


\section{Ethno-medicinal plant drugs}

\section{Materials and Methods}

The different parts of five ethno-medicinal plant drugs, A. serphyllifolia (leaves), D. hispida (tubers); G. mauritiana (leaves); $N$. nimmoniana (leaves) and $R$. densiflora (whole plant) were collected from different tracts/regions of B.R. Hills of Chamaraja Nagara districts of Karnataka (Fig. 1A-H).

\section{Instruments}

The instruments such as, Electric blender, Microscope (Olympus), Muffle furnace (Meta lab, Scientific industries, Mumbai), Centriguge (REMI R-4C \& 8RC Centrifuge Machine Bengaluru), Soxhlets Apparatus (Multiple Units), Flash Evaporator, Shaker incubator, Laminar Air Flow (Meditech, Chennai), Spectrophotometer (UV/Visible, Elico Limited, Hyderabad) etc. were employed in the study.

\section{Chemicals}

In the study, the standard chemicals of analytical grade were used namely, Picric acid, $\alpha$-naphthol, Benedict's reagent, $5 \%$ Ferric chloride, $1 \%$ Gelatin, $10 \%$ sodium hydroxide, Alcohol, Biuret's reagent, Ninhydrine reagent, Lead acetate, $\mathrm{NaOH}$, Conc. $\mathrm{H}_{2} \mathrm{SO}_{4}$, copper sulphate, dimethylsulfoxide (DMSO), di-sodium hydrogen orthophosphate $\left(\mathrm{Na}_{2} \mathrm{HPO}_{4}\right)$, ethylenediamine tetracetic acid (EDTA), Folin Ciocalteu's phenol (FC) reagent. Besides, the chemicals used in the study were of, 3(4,5-dimethylthiazol-2-yl)2,5-diphenyl-tetrazolium bromide (MTT), rutin, gallic acid followed by ferric chloride $\left(\mathrm{FeCl}_{3}\right)$, hydrogen peroxide $\left(\mathrm{H}_{2} \mathrm{O}_{2}\right)$, Hydroxylamine hydrochloride, sodium dodecyl sulphate (SDS), magnesium sulphate $\left(\mathrm{MgSO}_{4}\right)$, potassium chloride $(\mathrm{KCl})$, magnesium chloride $\left(\mathrm{MgCl}_{2}\right)$, sodium hydroxide $(\mathrm{NaOH})$, sodium chloride $(\mathrm{NaCl})$, sodium dihydrogen-orthophosphate $\left(\mathrm{NaH}_{2} \mathrm{PO}\right.$ ), trichloroacetic acid (TCA), and Tris-HCl were obtained from Sisco Research Lab., (Mumbai, India). Additionally, other specific solvents and reagents of analytical grade were used in the studies, which were procured from authorized S.D. Fine chemicals Pvt. Ltd., followed by Merck, India. The media like, agar, cholesterol, hypochlorite solution, proteose peptone and yeast extract were procured from Hi-Media, (Mumbai), India (Deng et al., 2006; Zakaria et al., 2011).

\section{Interaction with Tribal Medicine Men and collection of Ethno-medicinal plants}

The interactions were conducted intermittently with Tribal Medicine Men at the different locale of Biligirirangana Hills, Karnataka (during the period, 2013-2014) with a semi-structured questionnaire. The data on Medicine formulation and responsible plant components were documented and the Herbal Medicine Formulations (HMF) and individual ethno-medicinal plant materials were obtained from the Tribal Medicine Men (Fig. 3A-J). The particulars on atypical practiced medicine formulation comprising different parts of ethno-medicinal plants such as, Andrographis serphyllifolia, Vahl (leaves), Discorea hispida, Dennst, (tubers); Glycosmis mauritiana Tanaka, (leaves); Nothapodytes nimmoniana Blume (leaves) and Rawolfia densiflora (Wall.) Benth \& Hook (whole plant) respectively were explicitly collected during the interaction. The plants species were identified and authenticated by consulting a taxonomist followed by standard flora, correspondingly, the plant materials were deposited at Bhoomigeetha Institute of Research \& Development, (Tumkur), Karnataka, India. The baseline informations of selected ethno-medicinal plants are represented in the Table 1.

\section{Validation of Tribal Medicine Formulation (HMF)}

The different plants samples of Tribal medicine formulation were scientifically validated based on their physical characteristics in association with an authorized Ayurvedic practitioner, Nisarga Ayurveda Research Foundation, Sakaleshpur, Hassan district, India (Table 1). The standard protocols were identified and the methodology was employed in the present study based on the descriptions of Chaithra (2013).

\section{Preparation and Processing of HMF}

The collected ethno-medicinal plant materials of HMF were subjected for unraveling different desirable parts like, leaves, stem, root/ tubers from the main plants or whole plant parts. The different parts of the selected ethno-medicinal plant drug materials were subjected for shade drying for 20 days to ensure that, the active constituents were free from decomposition and possibility of photo-chemical degradation was also monitored. The whole HMF formula and its components were extracted by following the traditional process i.e., boiling with water for 15 minutes followed by filtering the same using muslin cloth then, the filtrates were dried by means of lyophilization processes. Further, the dried extracts of HMF were examined to determine antioxidant, antiproliferative and apoptotic activities as per the standard analytical procedures (Anonymous, 2002).

\section{Preparation of Solvent extracts}

The air-dried components of the HMF drug were powdered using a suitable mechanical grinder to obtain a coarse powder, which was then subjected to successive solvent extraction with ethanol, methanol and petroleum ether in a soxhlet apparatus. The material was dried in hot air oven at $40^{\circ} \mathrm{C}$ each time before extracting with the 
next solvent. The extracts were then filtered through a Whatman No.1 filter paper and concentrated to the dry mass using rotary evaporator. The extraction process was repeated for three times at different time intervals. The yield of each extract was measured and residues were stored in dark glass tubes for further analysis.

\section{Phyto-chemical analysis of EMP and HMF}

The extracts from ethno-medicinal plant (EMP) drugs and Tribal Medicine Formulation (HMF) were used for the Phyto-chemical analysis qualitatively for the detection of carbohydrates, proteins followed by the secondary metabolites like alkaloids, flavonoids, terpenoids, steroids, tannins, saponins and total phenols etc. The aqueous extracts of the plant was subjected to qualitative chemical screening for the identification of the alkaloids, flavonoids and tannins using standard procedures (Trease, G. E.; and Evans 1996; Kokate et al., 2004; Mondal, et al.,2013).

\section{ABTS radical scavenging activity}

The ABTS assay (2, 2-azinobis 3-ethylbenzothiazoline-6-sulfonic acid) was performed by preparing a stock solution which is consisting of $7 \mathrm{mM}$ ABTS solution and $2.45 \mathrm{mM}$ potassium persulfate solution at equal proportion. This was subjected for incubation at room temperature for $12 \mathrm{~h}$ during dark condition that was further yielded a dark colored solution which contains radicals of ABTS. Subsequently, to perform each assay, the fresh working solution was prepared by mixing stock solution with methanol $(50 \%)$ and the initial absorbance was $0.700( \pm 0.02)$ at $745 \mathrm{~nm}$ at $30^{\circ} \mathrm{C}$ temperature. Further, the extracts of ethno-medicinal plant drugs and tribal medicine formulation were used at variable concentrations $(50-3000 \mu \mathrm{g} / \mathrm{ml})$. Then, these concentrations were subjected for reaction with known volume $(3 \mathrm{ml})$ of ABTS solution and the absorbances were taken at $734 \mathrm{~nm}$. Meanwhile, the ascorbic acid was taken as positive control. Finally, the radical scavenging activity was assessed based on the percent activity of ABTS and calculated the value as per the standard formula (Re et al., 1999).

\section{ABTS radical scavenging activity $(\%)=$ Control OD - Sample OD $\times 100$ \\ Control OD}

\section{Thin Layer chromatography (TLC)}

Thin layer chromatography (TLC) is a chromatography technique used to separate diverse concoction of bioactive constituents. Thin layer chromatography is performed on a sheet of glass, plastic, or aluminum foil, which is coated with a thin layer of adsorbent material, usually silica gel, aluminium oxide, or cellulose. This layer of adsorbent is known as the stationary phase. After the sample has been applied on the plate, a solvent or solvent mixture (known as the mobile phase) is drawn up the plate via capillary action. Because different analytes ascend the TLC plate at different rates, separation is achieved and the compounds in the extracts gets separated based on their affinity. The fluorescence bands were observed at $254 \mathrm{~nm}$ (short wavelength) in UV light followed by $366 \mathrm{~nm}$ (long wavelength) using UV light in the respective plates. After the run, plates were dried and sprayed with NP/PEG reagents were used to detect the bands on the TLC plates and the observation of chromatograms was done under long wavelength UV followed by visible light. The movement of the active compound was expressed by its retention factor (Rf), values were calculated for different samples (Wagner and Bladt, 2009).

$$
\mathrm{Rf}=\frac{\text { Distance travelled by the solute }}{\text { Distance travelled by the solvent front TLC plates }}
$$

\section{Cell Lines and Cell Culture Preparation}

The Cell- lines used in this study were of estrogen receptor-positive 'MCF-7' breast cancer cells and cervical 'HeLa' cancer cells. The MCF-7cancer cells were cultured in 89\% DMEM and 10\% FBS along with 1\% penicillin/streptomycin. Similarly, the HeLa, cells were cultured in 89\% RPMI 1640 with $10 \%$ FBS and $1 \%$ penicillin/streptomycin. All the cells were cultured at $37{ }^{\circ} \mathrm{C}$ at $95 \%$ humidity and $5 \% \mathrm{CO}_{2}$ for 3 days as they reached $80 \%-90 \%$ confluency. Subsequently, the spent medium was removed and replaced with fresh medium and incubated again for $24 \mathrm{~h}$. The cell cultures were then washed with PBS 1-2 times and were suspended using trypsin-EDTA and finally, fresh medium was added to the cells (Evan and Vousden, 2001).

\section{Anti-proliferative activity}

Anti-proliferative activity was measured by MTT assay and that was performed using 96-well plate at a cell density of $3 \times 103$ cells/well. The cancer cells, MCF-7 and HeLa were subjected for analysis using precultured by Minimum Essential Medium (MEM) containing 10\% Fetal Bovine Serum (FBS) and as per their specificity described above. All the cell lines were pre-cultured for $24 \mathrm{~h}$ before confronting with variable concentration of the extracts i.e., 10,30,100,300, and 1,000 $\mu \mathrm{g} / \mathrm{ml}$. Then, phosphate buffer saline (PBS) was used as negative control and adriamycin was used as positive control, finally subjected for incubation as per the 
protocol explained above (Nesaretnam et al., 1998; Sun et al., 2002; Giri et al., 2006; Siripong et al., 2006; Hu et al., 2011). After the incubation period $(72 \mathrm{~h})$, the treated cells were added with MTT reagent then incubated again for $3 \mathrm{~h}$ and the formozan salts were dissolved with DMSO. The absorption was measured at $550 \mathrm{~nm}$. The concentration that inhibited $50 \%$ cell growth $\left(\mathrm{IC}_{50}\right)$ was calculated using curve fitting and the each experiment was done in 3 replicates and reported as $\mathrm{IC}_{50} \pm \mathrm{SD}$ (Elumalai et al., 2012).

\section{MTT bioassay}

The cytotoxic effect in different active fractions of HMF drug was evaluated against MCF-7 using MTT bioassay (Sanaz et al., 2012). The human breast cancer MCF-7 Cell line was cultured explicitly as mentioned in the procedure. Accordingly, the cells were seeded in 96 -well microtitre plate $(200 \mu \mathrm{l} /$ well $)$ with concentration of $4 \times 104$ cells $/ \mathrm{cm}^{2}$. The cultivated cells were exposed to various concentration of the methanolic extract $(1,0.75,0.5$, $0.25,0.1,0.075,0.05,0.025,0.01 \mathrm{mg} / \mathrm{mL}$ ) prepared in $1 \%$ dimethyl sulfoxide (DMSO) as they reached $40-50 \%$ confluency and were then incubated for different periods of time (24, 48 and $72 \mathrm{~h})$. The control groups received the same amounts of DMSO with four wells remained untreated as control. After the treatment, normal culture medium was replaced with $200 \mu \mathrm{l}$ fresh media and $50 \mu \mathrm{l} \mathrm{MTT}$ reagent $(2 \mathrm{mg} / \mathrm{mL}$ in PBS), except the cell-free blank control wells. The cells were maintained vi incubation as per the procedure mentioned above subsequently, the MTT solution was substituted with $200 \mu \mathrm{l}$ of DMSO and $25 \mu \mathrm{l}$ sorenson buffer $(0.1 \mathrm{M} \mathrm{NaCl}, 0.1 \mathrm{M}$ glycine regulated to $\mathrm{pH}$ : 10.5 with $1 \mathrm{M} \mathrm{NaOH}$ ), incubated for $15 \mathrm{~min}$ at $37^{\circ} \mathrm{C}$. Eventually, the optical density of the wells was measured at $570 \mathrm{~nm}$ by means of a spectrophotometric plate reader of standard firm. The growth of tumoral cells and viability of the cells was determined using the formula.

Viability $\%=$ (optical density of sample/optical density of control) $\times 100$

Furthermore, the cyto-toxicity of the HMF extract was determined by plotting of the percent cyto-toxicity index, CI $\%=[1$-(optical density of sample/optical density of control) $] \times 100$, versus concentrations of the fractions of Tribal medicine formulation.

\section{Evaluation of Anticancer activity from HMF drug formula}

The concept of making dilution which is a process of declining the concentration by adding of a solution such as water. The crude extracts of HMF drug was diluted according to the requirements and the extracts were syringe flittered to avoid contamination prior to use.

\section{Trypan Blue Assay}

Trypan blue is an imperative stain applied to examine the dead tissues or the cells which takes blue colour selectively. This assay is used to determine the dead cell count as well as the living cell count. The living cells will have an intact membrane which does not allow the dye to pass since the cells are very selective in compounds. The dead cell does not process an intact membrane and takes up the stain.

\section{Hoechst Stain Assay}

This assay was done to check that the cell death has occurred due to apoptosis (the cell death due to destruction in the actual functions of membrane followed by cells that in turn leads to inflammation) or not. Besides, Hoechst Stain assay was done to confirm that, the cell death has occurred explicitly due to apoptosis only.

\section{MTT Assay}

The MTT assay was performed to reduce the yellow composite called 3-(4,4-dimethylthiazol-2-yl)-2,5diphenyl tetrazolium bromide (MTT) under the influence of succinate dehydrogenase enzyme in the complex-II at the electron transport chain that occurs in Mitochondria. The turn down of MTT can occur only physiologically active cells so, the activity will be determined based on the viability status of the cells. The whole reaction comprises, the MTT which go into the cell subsequently to the mitochondria wherein, MTT was reduced to form an insoluble Formosan product which appears in dark purple color. Meanwhile, the cells are solubilized through DMSO solvent thus, the released Formosan product was assessed through spectrophotometric method (Mosmann, 1983).

\section{Results}

The present study was carried out at the Department of Engineering Chemistry, Maharaja Institute of Technology, (Visvesvaraya Technological University), Thandavapura, Nanjanagud taluk, Mysuru dist - 571302, (Karnataka), India and the analytical study was conducted at the department of Biotechnology and applied sciences, SIET, Tumkur. The herbal/tribal medicine formulation was validated in association with Bhoomigeetha Institute of Research and Development (BIRD), Tumkur. The anti-cancer study was executed in association with Sri Raghavendra Biotechnologies, Bengaluru. The HMF (Tribal Medicine Formula) or Herbal Medicine Formula 
(HMF) was procured from traditional practitioner at Biligirirangana Hills, Chamarajanagara district, Karnataka (Table 1 and Fig 1).

\section{Phyto-chemical analysis}

The phyto-chemical screening of aqueous extract and solvent extracts of EMP and HMF demonstrated the presence of Carbohydrate, proteins, alkaloids, flavonoids, saponins, tannins, gums \& mucilages, coumarins, terpenoids, tannins, steroids, glycosides, phyto sterols, fixed oils and fats, phenols, saponin etc in Cold water, hot water followed by solvent extracts. The presence of these phyto-chemicals suggested to taking part in synergistic role to exert the observed pharmacological activity. The fact that strong synergism of several constituents in the crude drug may prove more potent and effective than any single purified compound, is always overlooked. Moreover, this may help to nullify the toxic effects (if any) of individual constituents (Table 2).

\section{Antioxidant activity}

The method used, ABTS radical scavenging assay, gave the measure of antioxidant activity of the HMF drug extract determined by the decolorization of the $\mathrm{ABTS}^{+}$, through measuring the reduction of the radical cation as the percentage inhibition of absorbance at $734 \mathrm{~nm}$. The effects of HMF drug aqueous extract on ABTS free radical scavenging activities was assayed at various concentrations. The $\mathrm{IC}_{50}$ value was found to be $07 \pm 0.74 \mu \mathrm{l} / \mathrm{ml}$ was evident in this extract (Table 3 ).

\section{Chromatographic studies}

This was done in order to purify the HMF drug solvent extracts and the TLC chromatograms were developed using the solvent system, toluene, chloroform and ethanol. The bioactive compound moved on the stationary phase was measured and the retention factor was calculated. There were two to five bands of whole HMF drug extract at Rf values of 0.32 and 0.44 in A. serpyllifolia; 0.52 and 0.26 in D.hispida; 0.59 and 0.23 in $G$. mauritiana; $0.34,0.14,0.16,0.62$ and 0.95 in N.nimmoniana similarly, in case of $R$. densiflora 0.76 and 0.85 were present. The extracts showed variable Rf values as compared among these extracts (Table 4 and Fig.2A\&B).

\section{Anticancer activity}

The partially purified extract of HMF drug was tested for anticancer property against both HeLa and MCF-7 cell lines respectively. The inhibition concentration $\left(\mathrm{IC}_{50}\right)$ as observed from the graph lies between 3 and 4 in 24 hours of trypan blue assay (Table 5 and Fig. 3, 8, 10 \& 11). The cells show positive Hoechst assay as the DNA has acquired the Hoechst stain and the same is seen under the fluorescent microscope as observed (Fig. 14 \& 17).

The result analysis for MTT assay shows that, the cell viability decreases with the increase in concentration of the HMF drug. The inhibition concentration value $\left(\mathrm{IC}_{50}\right)$ for MTT assay at 24 hours showed to be $3 \%$ and for 48 hours (Table $6 \& 7$ ) lies in between 3 and 4 (Fig. 4,5,6,7 and 9A \&B). The positivity of the MTT Assay can be observed in the fig 5 and 7 by the formation of crystals.

\section{Anticancer activity against MCF-7 Cell Lines}

The cells were cultured on the suitable Animal cell media under controlled condition and the various concentrations of the formulation was taken and tested for its action on the growth of HeLa cells and Mammarian Cancer cells (MCF-7). The Anticancer activity was determined using the 'Tryphan Blue assay' in Table 5. This result revealed that, profound activity was noticed by the end of 24 hours than 48 hours shown in Fig. 8, 10, 11,12 $\&$ 16. Then, the Cell viability count was determined through MTT assay along with a media control contained growing cells with no drug. Similarly, the vehicle control was set up in presence of the respective solvents. The ethanolic extract of HMF drug was tested against HeLa cells followed by MCF-7 cell lines (Fig. 4,5, 6,7 and 9A $\& B)$. The HMF drug extract was found to be superior as compared to other extracts. The result reveals the apoptosis of both cancer cells indicating the most positive action of the Herbal Medicine formulation (Fig.12,13 \&14).

The 'Hoechst staining' technique was showed the apoptotic state of cells and DNA, through fluorescent microscopy. The remarkable activity was noticed in the HMF drug tested in its crude form compared to the purified form which confirms that, the HMF drug works best in its crude form which is being currently practiced by the Traditional healers (Fig. 15, $16 \& 17$ ).

\section{Discussion}

The presence of active secondary metabolites in the extracts of ethno-medicinal plants may have profound activity and justifies the status for preparation of crude potential drug by the tribal people. The phytochemical screening of the ethno-medicinal plants showed the presence of alkaloids, flavonoids, terpenoids, saponins, tannins, phenolic compounds and reducing sugars. A. serphyllifolia and D. hispida did not contain 
cardiac glycosides and coumarins while, G. mauritiana, $N$. nimmoniana and $R$. densiflora showed the presence of glycosides, tannins and alkaloids. The phyto-chemical analysis conducted on the plant extracts revealed the presence of constituents which are known to exhibit medicinal as well as physiological activities (Sofowora, 1993). The TLC result in the different components of HMF drug exhibited the presence of diversified bioactive constituents and confirms the overall potentiality of the HMF drug.

The MTT assay on the cytotoxic activity of the partially purified extract of HMF plant drug on MCF-7 cell line apart from experimentation with HeLa cells suggested that, the extract was fairly cytotoxic to MCF-7 cells in a dose and time dependent manner. The findings of the present study will provide an insight into a new implication of the traditional usage of HMF drug in the tribal medicine system found to be as a most potential, efficacious and novel cancer chemo-preventive agent, where integration of the different herbal compositions remedy may help in preventing or reducing the risk of breast cancer and associated oxidative stress diseases. The similar expressions were also made in traditional medicinal plants (Abdul et al., 2009; Althunibat et al., 2009; Rajesh et al., 2011; Cieckiewicz et al., 2012).

Several studies in this filed have shown that, the ethno-medicinal plants are of potential value for identifying anti-proliferative agents followed by determination of the anti-inflammatory and anti-proliferative activity of herbal medicine formulation where, the suppression of cell growth as well as induction of apoptosis in human breast cancer cells was observed (Conforti et al., 2008; Nurhanan et al., 2008; Hogan et al., 2010; Mbaveng et al., 2011; Lin et al., 2012). Elsewhere, metabolites like, flavonoides, di-terpenoids and poly phenols from Herbal Medicine formulation was appraised for their Cytotoxic effects against both MCF-7 and HeLa cancer cell lines respectively. This expression from the study revealing that, the HMF has strong tumor regression potentiality even for a broad range of tumor cells depicted in the ailment. This is in accordance with the reports of Sun et al., (2002); Matito et al, (2003); Giri et al, (2006); Hu et al, (2011); Elumalai et al., (2012).

In addition, this study has clearly shown that, HMF drug has relatively substantial antioxidant activity with regard to the potential constituents present in it that might be responsible for the chemo-preventive effects of the HMF drug extract. The protective role and consistency of these active compounds of the HMF drug might have connected to the ailment in controlling the various oxidative stress factors (Braca et al., 2002; Matito et al., 2003; Aiyegoro et al., 2009; Tyagi et al., 2010; Murthy et al., 2011; Hu et al., 2011; Hazirah et al., 2013). The different endogenous antioxidants produced by the human body have potential health benefits against oxidative stress and related ailments, but also naturally supplemented herbal antioxidant compounds such as, phenolic acids, polyphenols and flavonoids scavenge free radicals like peroxide, hydroperoxide or lipid peroxyl are most promising and inhibits the oxidative mechanisms to prevent the system from degenerative diseases (Bhandari and Kawabata, 2004; Barriera et al., 2008; Aiyegoro and Okoh, 2010; Verma et al., 2009; Hogan et al., 2010; Yang et al., 2010).

In addition, this study has clearly shown that, the active fractions of HMF drug has antioxidant activity and comparatively high with regard to the potential radical scavenging ability of its methanolic extract. Since, the HMF drug are normally comprising complex mixtures of different active metabolites i.e., flavonoids, alkaloids and other phenolic compounds present in the methanolic extract of HMF drug which further donates a hydrogen atom for scavenging the stable DPPH radical, would be beneficial in quantifying the presumed charge of them as antioxidant and anti-cancer agents (Oskoveian et al., 2011; Hazirah et al., 2013).

The exceptional fact that, anticancer activities of ethno-medicinal plants have been verified critically to be coupled with a diverse range of phyto-chemicals, such as polyphenols, flavonoids, terpenoides, steroids, catechins etc (Tung et al., 2009). Many researchers have also opined that, the more phenolic content of different plant components increases the antioxidant activity in the system since, there is a linear correlation between phenolic contents and antioxidant activity (Prasad et al., 2009; Hogan et al., 2010; Jain and Jain, 2011; Nagmoti et al., 2012). Although, the phenolics of plant sources are very basis for antioxidants, in which they have differential expressions along with a specific ability to quench various free radicals. As a result, verifying the role of these phyto-chemicals in HMF drug, certain kind of an oxidative stress related diseases is of substantial importance. In the study, there is a correlation between total active phyto-chemicals with special reference to phenolic and flavonoids contents as well as radical scavenging activity along with the anti-prolifreative activity of breast cancer in the active fractions of HMF drug was explored.

By taking into account, the results on cyto-toxicity in the extracts of HMF drug at MCF-7 cells was found to be superior with increased contents of both phenolics and flavonoids and thereby, higher radical scavenging activity in higher concentrations was noticed. On the whole, this study suggests, the potentialities of both antioxidant and cytotoxic activities of HMF extract which could be helpful in preventing or curbing the progress of various oxidative stress-related diseases such as breast cancer. This was evident in the approaches on bioassayguided fractionation in HMF drug, further it would be of value to purify and identify the foremost active constituents in the extract which is responsible for inhibiting the proliferation of MCF-7 cells in the system (Ksouri et al., 2009; Fu et al., 2010). Similarly, as some phenolic antioxidants have a specific role in suppressing the growth and proliferation of transformed or malignant cells through induction of programmed cell death or 
Evaluation of validated herbal medicine formulation for Anti-proliferative and apoptotic activities ..

apoptosis, it materializes to demand the need for additional investigation on cell cycle analysis and determination of the distinctive mechanism of action for providing anti-prolifreative activity in the extract of Herbal Medicine formulation (Puneeth kumar et al., 2011; Oskoueian et al., 2011; Sanaz et al., 2012). The authors believe that, the current objectives of the study could furnish the appropriate background for detailed examination on anticancer properties of this HMF drug. Besides, it is the very first report on the analysis of the anti-proliferative (MCF-7) and antioxidant activities of Herbal Medicine formulation being practiced in the Tribal Medicine System (TMS).

\section{Conclusion}

Finally, it can be concluded that, the Herbal medicine formulation has potent antimicrobial and antioxidant activities apart from their antiproliferative activities. Hence, with this basis, the formulation showed the highest anticancer activity against MCF-7 Cell lines and justifies their practice of Herbal Formulation in their TMS. Further, the susceptibility of mammarian cancer cells has been influenced by HMF drug has been substantiated based on the outcome of the study. In addition, the significance of these observations and recommendations in the light of previous studies with asynchronous population of MCF-7 cells also has been discussed.

\section{Acknowledgements}

The authors would like to express thanks to the authorities of Jawaharalal Nehru Technological University, Ananthapuramu (AP), India for providing the opportunity to carry-out this Research study. The first Author would like to thank the authorities of Department of Chemical Engineering and Biotechnology along with Oil Technological and Pharmaceutical Research Institute (OTPRI) for their guidance and cooperation. Further, sincere thanks to Maharaja Institute of Technology, Thandavapura (Visvesvaraya Technological University, Belagavi), Nanjanagud Tq, Mysuru dist-571302, India for providing basic infrastructure for conducting preliminary studies. In addition, the author is also thankful to Sri Raghavendra Biotechnologies, Bengaluru for their association with human cancer cell lines and laboratory facilities to complete the objectives successfully. The authors are finally extending their grateful thanks to Bhoomigeetha Institute of Research \& Development (BIRD), Tumkur for providing the ethno-medicinal plant materials with taxonomical identification and formulations (HMF / HMF) and for their assistance in scientific validation.

\section{References}

[1]. Abdul, A.B., Abdelwahab, S.I., Fong, H.K., Mohan, S.M., Al-Zubairi, A.S., Elhassan, M.M. 2009. In vitro response of cancer cells to the growth-inhibitory effects of dichloromethane extract of Goniothalamus umbrosus. Res. J. Pharmacol., 3, 1-6.

[2]. Adedapo, A.A., Jimoh, F.O., Afolayan, A.J, Masika, P.J. 2008. Antioxidant activities and phenolic contents of the methanol extracts of the stems of Acokanthera oppositifolia and Adenia gummifera. BMC Complement Altern Med, 8, 54.

[3]. Aiyegoro, O.A., Okoh, A.I. 2009. Phytochemical screening and polyphenolic antioxidant activity of aqueous crude leaf extract of Helichrysum pedunculatum. Int. J. Mol. Sci., 10, 4990-5001.

[4]. Aiyegoro, O.A., Okoh, A.I. 2010. Preliminary phytochemical screening and in vitro antioxidant activities of the aqueous extract of Helichrysum longifolium DC. BMC Complement. Altern. Med., 10, 21.

[5]. Akim, A., Ling, L.C., Rahmat, A. and Zakaria, Z.A. 2011. Antioxidant and anti-proliferative activities of Roselle juice on Caov-3, MCF-7. MDA-MB-231 and HeLa cancer cell lines. Afr. J. Pharm. Pharmacol., 5, 957-965.

[6]. Al-Rashidi, W., Mat Supri, N.N., Manshoor, N. 2011. Cytotoxic activity of crude extract from Costus malortieanus (Costaceae). Am.Eurasian J. Toxicol. Sci., 3, 63-66.

[7]. Althunibat, O.Y., Hashim, R.B., Taher, M., Daud, J.M., Ikeda, M.A., Zali, B.I. 2009. In vitro antioxidant and antiproliferative activities of three Malaysian sea cucumber species. Eur. J. Sci. Res., 37, 376-387.

[8]. Anonymous. 2002. Wealth of India. First supplementary Series, Vol-3, (D-I), Raw materials. Niscom. 130.

[9]. Anusha Kulkarni., Ramya, M.C and Panduranga Murthy, G. 2010. Evaluation of Tribal Medicine and Active Principle of Glycosmis Mauritiana (Lam) Tanaka for Antioxidant and Anticancer activity against Pc-3 Cell Lines. $34^{\text {rd }}$ Series, SPP KSCST Projects, 45-46.

[10]. Atjanasuppat, K., Wongkham, W., Meepowpan, P., Kittakoop, P., Sobhon, P., Bartlett, A., Whitfield, P.J. 2009. In vitro screening for anthelmintic and antitumour activity of ethnomedicinal plants from Thailand. $J$. Ethnopharmacol., 123, 475-482.

[11]. Aune, D., De Stefani E, Ronco, A. 2009. Fruits, vegetables and the risk of cancer: a multisite case-control study in Uruguay. Asian. Pac. J. Cancer Prev., 10, 419-28. 
[12]. Barreira, J.C.M., Ferreira I.C.F.R., Oliveira, M.B.P.P., Pereira, J.A. 2008. Antioxidant activities of the extracts from chestnut flower, leaf, skins and fruit. Food Chem, 107, 1106-1113.

[13]. Bhandari MR, Kawabata M. 2004. Organic acid, phenolic content and antioxidant activity of wild yam (Dioscorea spp.) tubers of Nepal. Food Chem, 88:163-168.

[14]. Boopathy NS, Kathiresan K. 2010. Anticancer drugs from marine flora: an overview. J Oncol, 214186:18.

[15]. Braca A, Sortino C, Politi M. 2002. Antioxidant activity of flavonoids from Licania licaniae flora. $J$ Ethnopharmacol, 79:379-381.

[16]. Caamal-Fuentes, E., Torres-Tapia, L.W., Simá-Polanco, P., Peraza-Sánchez, S.R., Moo-Puc, R. 2011. Screening of plants used in Mayan traditional medicine to treat cancer-like symptoms. J. Ethnopharmacol., 135, 719-724.

[17]. Chaithra, D, Nisaraga Ayurvedic Research Foundation, Sakaleshpur, Hassan district (India): Validated Tribal Medicine formulation (HMF): Ref. No.176/2013.

[18]. Cieckiewicz, E., Angenot, L., Gras, T., Kiss, R., Frédérich, M. 2012. Potential anticancer activity of young Carpinus betulus leaves. Phytomedicine, 19, 278-283.

[19]. Conforti, F., Ioele, G., Statti, G.A., Marrelli, M., Ragno, G., Menichini, F. 2008. Antiproliferative activity against human tumor cell lines and toxicity test on Mediterranean dietary plants. Food Chem. Toxicol., 46, 3325-3332.

[20]. Deng XK, Yin W, Li WD, Yin FZ, Lu XY, Zang XC, Hua ZC, Cai BC. 2006. The antitumor effects of alkaloids from the seeds of Strychnos nux-vomica on HepG2 cells and its possible mechanism. $J$ Ethnopharmacol, 106:179-186.

[21]. Diwanay, S., Chitre, D., Patwardhan, B. 2004. Immunoprotection by botanical drugs in cancer chemotherapy J Ethnopharmacol., 90: 49-55.

[22]. Elumalai, P., Gunadharini, D.N., Senthilkumar, K., Banudevi, S., Arunkumar, R., Benson, C.S., Sharmila, G., Arunakaran, J. 2012. Ethanolic neem (Azadirachta indica A. Juss) leaf extract induces apoptosis and inhibits the IGF signaling pathway in breast cancer cell lines. Biomed. Prev. Nutr., 2, 59-68.

[23]. Evan, G.I, Vousden, K.H. Proliferation, cell cycle and apoptosis in cancer. Nature 2001, 411:342-348

[24]. Fu, W., Chen, J., Cai, Y., Lei, Y., Chen, L., Pei, L., Zhou, D., Lang, X., Ruan, J. 2010. Antioxidant, free radical scavenging, anti-inflammatory and hepatoprotective potential of the extract from Parathelypteris nipponica (Franch. et Sav.) Ching. J. Ethnopharmacol., 130, 521-528.

[25]. Giri, B., Gomes, A., Debnath, A., Saha, A., Biswas, A.K., Dasgupta, S.C. 2006. Antiproliferative, cytotoxic and apoptogenic activity of Indian toad (Bufo melanostictus, Schneider) skin extract on U937 and K562 cells. Toxicon, 48, 388-400.

[26]. Gul MZ, Bakhshu LM, Ahmed F, Kondapi AK, Qureshi IA, Ghazi IA. 2011. Evaluation of Abelmoschus moschatus extracts for antioxidant, free radical scavenging, antimicrobial and antiproliferative activities using in vitro assays. BMC Complement Altern Med, 11:64.

[27]. Hasan TN, B LG, Shafi G, Al-Hazzani AA, Alshatwi AA. 2011. Anti-proliferative effects of organic extracts from root bark of Juglans regia L. (RBJR) on MDA-MB-231 human breast cancer cells: role of Bcl-2/Bax, caspases and Tp53. Asian Pac J Cancer Prev, 12, 525-30.

[28]. Hazirah, A., Zainal, B., Abdah, M. 2013. Total phenolic content, antioxidant and cytotoxic activity of cocoa (Theobroma cacao L.) polyphenols extracts on cancer cell lines. Malays. J. Nutr., 19, 223-232.

[29]. Hinneburg I, Dorman HJD, Hiltunen R. 2006. Antioxidant activities of extracts from selected culinary herbs and spices. Food Chem, 97:122-129.

[30]. Hogan S, Chung H, Zhang L, Li J, Lee Y, Dai Y, Zhou K. 2010. Antiproliferative and antioxidant properties of anthocyanin-rich extract from acai. Food Chem, 118:208-214.

[31]. Hossain, M.A., Shah, M.D., Gnanaraj, C., Iqbal, M. 2011. In vitro total phenolics, flavonoids contents and antioxidant activity of essential oil, various organic extracts from the leaves of tropical medicinal plant tetrastigma from Sabah. Asian Pac. J. Trop. Med., 4, 717-721.

[32]. Hu, W., Yu, L., Wang, M.-H. 2011. Antioxidant and antiproliferative properties of water extract from Mahonia bealei (Fort.) Carr. leaves. Food Chem. Toxicol., 49, 799-806.

[33]. Itharat, A., Houghton, P.J, Eno-Amooquaye E, Burke, P.J, Sampson, J.H, Raman, A. In vitro cytotoxic activity of Thai medicinal plants used traditionally to treat cancer. J Ethnopharmacol, 2004, 90: 33-38.

[34]. Jain, R., Jain, S.K. 2011. Screening of in vitro cytotoxic activity of some medicinal plants used traditionally to treat cancer in Chhattisgarh state, India. Asian Pac. J. Trop. Biomed., 1, S147-S150.

[35]. Jalil, A.M.M., Ismail, A., Pei, C.P., Hamid, M., Kamaruddin, S.H.S. 2008. Effects of cocoa extract on glucometabolism, oxidative stress, and antioxidant enzymes in obese-diabetic (Ob-db) rats. J. Agric. Food Chem., 56, 7877-7884.

[36]. Jemal, A., Siegel, R., Ward, E. 2006. Cancer Statistics. CA Cancer J Clin, 56, 106-30. 
[37]. Jones, W., Chin, Y., Kinghorn, A. 2006. The role of pharmacognosy in modern medicine and pharmacy. Curr Drug. Targets, 7, 247-64.

[38]. Kim, J .2008. Protective effects of Asian dietary items on cancers - soy and ginseng. Asian Pac J Cancer Prev, 9, 543-8.

[39]. Kokate, C.K., Purohit, A.P., and Gokhale, S.B., Practical Pharmacognasy, Vallabh Prakashan, Delhi. 2(ed.), 2004.

[40]. Ksouri, R., Falleh, H., Megdiche, W., Trabelsi, N., Mhamdi, B., Chaieb, K., Bakrouf, A., Magné, C., Abdelly, C: 2009. Antioxidant and antimicrobial activities of the edible medicinal halophyte Tamarix gallica L. and related polyphenolic constituents. Food Chem Toxicol, 47:2083-2091.

[41]. Lampronti, I., Martello, D., Bianchi, N., Borgatti, M., Lambertini, E., Piva, R., Jabbar, S., Choudhuri, M.S.K., Khan, M.T.H., Gambari, R. 2003. In vitro antiproliferative effects on human tumor cell lines of extracts from the Bangladeshi medicinal plant Aegle marmelos., Correa Phytomedicine, 10: 300-308.

[42]. Lin, H.-H., Chan, K.-C., Sheu, J.-Y., Hsuan, S.-W., Wang, C.-J., Chen, J.-H. 2012. Hibiscus sabdariffa leaf induces apoptosis of human prostate cancer cells in vitro and in vivo. Food Chem., 132, 880-891.

[43]. Ludwiczuk, A., Saha, A., Kuzuhara, T., Asakawa, Y. 2011. Bioactivity guided isolation of anticancer constituents from leaves of Alnus sieboldiana (Betulaceae). Phytomedicine, 18, 491-498.

[44]. Manian, R., Anusuya, N., Siddhuraju, P., Manian, S. 2008. The antioxidant activity and free radical scavenging potential of two different solvent extracts of Camellia sinensis (L.) O. Kuntz, Ficus bengalensis L. and Ficus racemosa L. Food Chem, 107:1000-1007.

[45]. Matito, C., Mastorakou, F., Centelles, J.J., Torres, J.L., Cascante, M. 2003. Antiproliferative effect of antioxidant polyphenols from grape in murine Hepa-1c1c7. Eur J Nutr, 42:43-49.

[46]. Mbaveng, A.T., Kuete, V., Mapunya, B.M., Beng, V.P., Nkengfack, A.E., Meyer, J.J.M., Lall, N. 2011. Evaluation of four Cameroonian medicinal plants for anticancer, antigonorrheal and antireverse transcriptase activities. Environ. Toxicol. Pharmacol., 32, 162-167.

[47]. Mishra, KP, Ganju L, Sairam M, Banerjee PK, Sawhney RC. 2008. A review of high throughput technology for the screening of natural products. Biomed Pharmacother, 62:94-98.

[48]. Moncada S, Palmer RMJ, Higgs EA. 1991. Nitric oxide: physiology, pathophysiology, and pharmacology. Pharmacol Rev., 43:109-142.

[49]. Mondal, S., Marouthu, I., Pushyami, P., and Suresh, P., Toxicity studies of ethanol extract from Ixora pavetta and rews leaf. World J. Pharm. Pharma. Sci. 3(1), 2013, 350-360.

[50]. Mosmann, T. 1983. Rapid colorimetric assay for cellular growth and survival: application to proliferation and cytotoxicity assays. J Immunol Methods, 65:55-63.

[51]. Nagmoti, D.M., Khatri, D.K., Juvekar, P.R., Juvekar, A.R. 2012. Antioxidant activity and free radicalscavenging potential of Pithecellobium dulce Benth seed extracts. Free Radic. Antioxid., 2, 37-43.

[52]. Nakayama, T.1994. Suppression of hydroxyperoxide-induced cytotoxicity by polyphenols. Cancer Res, 54:1991-1993.

[53]. Nesaretnam, K., Stephen R, Dils R, Darbre P. 1998. Tocotrienols inhibit the growth of human breast cancer cells irrespective of estrogen receptor status. Lipids, 33:461-469.

[54]. Nisa, S., Bibi, Y., Waheed, A., Zia, M., Sarwar, S., Ahmed, S., Chaudhary, M.F. 2011. Evaluation of anticancer activity of Debregeasia Salicifolia extract against estrogen receptor positive cell line. Afr. J. Biotechnol., 10, 990-995.

[55]. Nurhanan, M.Y., Asiah, O., Mohd Ilham, M.A., Siti Syarifah, M.M., Norhayati, I., Lili Sahira, H. 2008. Anti-proliferative activities of 32 Malaysian plant species in breast cancer cell lines. J. Trop. For. Sci., 20, 77-81.

[56]. Oskoueian, E., Abdullah, N., Saad, W.Z., Omar, A.R., Kuan, W.B., Zolkifli, N.A., Hendra, R., Ho, Y.W. 2011. Antioxidant, anti-inflammatory and anticancer activities of methanolic extracts from Jatropha curcas Linn. J. Med. Plants Res., 5, 49-57.

[57]. Panduranga Murthy,G., Punith kumar, T.G., Suresh,A., Ravishankar, H.G., Chandrasekhar, K.B and Lokesh, S.2011. Evaluation of ethanolic Leaf extract of Dioscorea hispida, Dennst. For Anti-inflamatory and Anti-analgesic activities. International Journal of Pharma and Industrial Research, Vol-1(2): 83-87.

[58]. Prasad, K.N., Hao, J., Shi, J., Liu, T., Li, J., Wei, X., Qiu, S., Xue, S., Jiang, Y. 2009. Antioxidant and anticancer activities of high pressure-assisted extract of longan (Dimocarpus longan Lour.) fruit pericarp. Innov. Food Sci. Emerg. Technol., 10, 413-419.

[59]. Prasanna, R., Harish, C.C., Pichai, R., Sakthisekaran, D., Gunasekaran, P. 2009. Anti-cancer effect of Cassia auriculata leaf extract in vitro through cell cycle arrest and induction of apoptosis in human breast and larynx cancer cell lines. Cell Biol. Int., 33, 127-134. 
[60]. Punithkumar, T.G., Panduranga Murthy, G., Suresh, G., Suresh,V., Senthilkumar, N and Ravishankar, H.G. 2011. Evaluation of Antitumour activity and Antioxidant status in Dioscorea hispida, Dennst. leaves on Ehrlich ascites carcinoma in Swiss albino mice. International Journal of Drug Development and Research, Vol: 3(2):203-210.

[61]. Rajesh, R., Chitra, K., Paarakh, P.M., Chidambaranathan, N. 2011. Anticancer activity of aerial parts of Aerva lanata Linn Juss ex Schult against Dalton's Ascitic Lymphoma. Eur. J. Integr. Med., 3, e245-e250.

[62]. Ramljak, D., Romanczyk, L.J., Metheny-Barlow, L.J., Thompson, N., Knezevic, V., Galperin, M., Ramesh, A., Dickson, R.B. 2005. Pentameric procyanidin from Theobroma cacao selectively inhibits growth of human breast cancer cells. Mol. Cancer Ther., 4, 537-546.

[63]. Ravelo, Á.G, Estévez-Braun A, Chávez-Orellana H, Pérez-Sacau E, Mesa-Siverio D.2004. Recent studies on natural products as anticancer agents Curr Top Med Chem, 4: 241-265.

[64]. Ravishankar, H.G and Panduranga Murthy, G. 2009. Ethno-medicinal wealth of Biligirirangana Hills (B.R. Hills), Karnataka, India. M.Phil thesis:Annamalai University, Tamilnadu (India), Data Base: Pp-1-415.

[65]. Rice-Evans, C. 2004. Flavonoids and isoflavones: absorption, metabolism and bioactivity. Free Radic Biol Med, 36:827-828.

[66]. Rice-Evans C.A, Miller N.J, Paganga G.1996. Structure-antioxidant activity relationships of flavonoids and phenolic acids. Free Rad Biol Med, 20:933-956.

[67]. Sanaz Hamedeyazdan, Fatemeh Fathiazad, Simin Sharifi, Hossein Nazemiyeh. 2012. Antiproliferative Activity of Marrubium persicum Extract in the MCF-7 Human Breast Cancer Cell LineAsian Pacific Journal of Cancer Prevention, 13, 5843-5848.

[68]. Sharma, J.V.C., Pitchaiah, G., Satyavati, D., Rao, J.V., Sanjay, H. 2011. In vitro anticancer activity of methanolic extract of roots of Glochidion zeylanicum (Gaertn.). Int. J. Res. Pharm. Biomed. Sci., 2, 760764.

[69]. Shoeb, M. 2006. Mini review anticancer agents from medicinal plants. Bangladesh J. Pharmacol., 1, 3541.

[70]. Sofowora, A., Medicinal Plants And traditional Medicine in Africa. Spectrum Books Ltd., Ibadan, Nigeria, 1993, 191-289.

[71]. Srinivasan P, Vadhanam MV, Arif JM, Gupta C. 2002. A rapid screening assay for antioxidant potential of natural and synthetic agents in vitro. Int J Oncol, 20:983-986.

[72]. Suffness M, Pezzuto JM: Assays related to cancer drug discovery. In Methods in Plant Biochemistry: Assays for Bioactivity, Volume 6. Edited by Hostettmann K. London: Academic, 1990:71-133.

[73]. Sun J, Chu YF, Wu X, Liu RH. 2002. Antioxidant and anti-proliferative activities of common fruits. $J$ Agric Food Chem, 50:7449-7454.

[74]. Szekanecz Z, Koch AE. 2007. Mechanisms of disease: angiogenesis in inflammatory diseases. Nat Clin Pract Rheum, 3:635-643.

[75]. Trease, G. E., and Evans, W. C., Pharmacognosy, 1996, 89-122 (London: Bailliere Tindall).

[76]. Tung YT, Wu JH, Huang CY, Kuo YH, Chang ST. 2009. Antioxidant activities and phytochemical characteristics of extracts from Acacia confuse bark. Bioresour Technol, 100:509-514.

[77]. Tyagi, S.N., Saxena, A., Patel, B.D. 2010. In vitro Antioxidant Activity of methanolic and aqueous extract of Flacourtia indica Merr. Am.-Eurasian J. Sci. Res., 5, 201-206.

[78]. Van PG.1993. Carotenoids and cancer: an update with emphasis on human intervention studies. Eur $J$ Cancer, 29(A):1335-1344.

[79]. Verma AR, Vijayakumar M, Mathela CS, Rao CV. 2009. In vitro and in vivo antioxidant properties of different fractions of Moring oleifera leaves. Food Chem Toxicol, 47:2196-2201.

[80]. Wangcharoen, W., Morasuk, W. 2007. Antioxidant capacity and phenolic content of chilies. Kasetsart J. Nat. Sci., 41, 561-569.

[81]. Wagner H, and Bladt S. Plant Drug Analysis, A Thin Layer Chromatography Atlas. 2nd ed. SpringerVerlag Berlin Heidelberg. 2009.

[82]. Woo, H.D, Kim, J. 2011. Nutritional epidemiology of cancer in Korea: recent accomplishments and future direactions. Asian Pac J Cancer Prev, 12, 2377-83.

[83]. Yang, J, Paulino R, Janke-Stedronsky S, Abawi F. 2007. Free radical scavenging activity and total phenols of noni (Morinda citrifolia L.) juice and powder in processing and storage. Food Chem, 102:302-308.

[84]. Yang, QM., Pan ,X.H., Kong, W.B., Yang, H., Su YD., Zhang, L., Zhang, Y., Yang, Y., Ding, L., Liu, G. 2010. Antioxidant activities of malt extract from barley (Hordeum vulgare L.) toward various oxidative stress in vitro and in vivo. Food Chem, 118:84-89.

[85]. Zakaria, Z.A., Rofiee, M.S., Mohamed, A.M., Teh, L.K., Salleh, M.Z. 2011. In vitro antiproliferative and antioxidant activities and total phenolic contents of the extracts of Melastoma malabathricum leaves. $J$. Acupunct. Meridian Stud., 4, 248-256. 

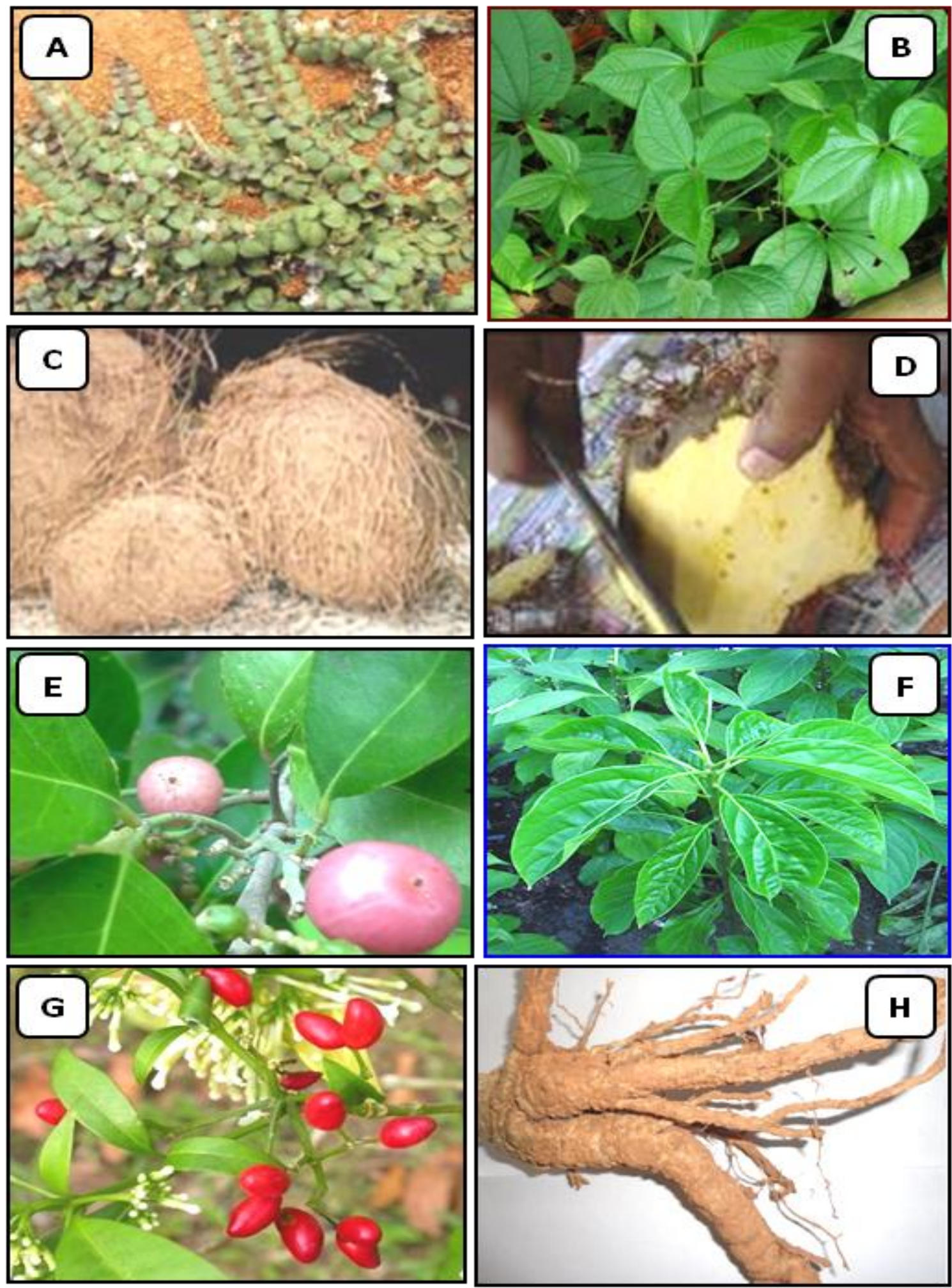

Fig. 1A-H: Ethno-Medicinal Plant Drugs (Emp) And Parts Of Tribal Medicinal Formulation (Hmf) A: Andrographis serphyllifolia, B: Dioscorea hispida, C \& D: Tubers of Dioscorea hispida; And processing of Tubers, E: Glycosmis mauritiana, F: Nothopodytes nimoniana, G \& H: Habit and Root samples of Rauwolfia densiflora, 
Table 1:Validated Tribal Medicine formulation (HMF) and its components practiced for antiproliferative and antiinflammatory related ailments at Biligirirangana Hill Tracts, Karnataka.

\begin{tabular}{|c|c|c|c|c|c|c|}
\hline $\begin{array}{l}\text { Sl. } \\
\text { No. }\end{array}$ & \multicolumn{2}{|c|}{$\begin{array}{l}\text { Ethno-medicinal plants with } \\
\text { Vernacular Name. }\end{array}$} & Family & $\begin{array}{l}\text { Plant parts } \\
\text { used }\end{array}$ & $\begin{array}{l}\text { Quantity } \\
\text { (powder) } \\
\text { (g/kg) }\end{array}$ & $\begin{array}{l}\text { Validated } \\
\text { Quantity of } \\
\operatorname{HMF}(\mathrm{g})^{*}\end{array}$ \\
\hline 1 & \multicolumn{2}{|c|}{$\begin{array}{l}\text { Andrographis serphyllifolia } \\
\text { Vahl. (A) } \\
\text { Vr. Name: Kasinasara }\end{array}$} & Acanthaceae & Whole plant & 20 & \multirow{5}{*}{$\begin{array}{l}\text { (A) 20+ } \\
\text { (D) 15+ } \\
\text { (G) 25+ } \\
\text { (N) 25+ } \\
\text { (R) } 15+ \\
\text { (HMF) } \\
\text { ADGNR } \\
=\text { 100g }\end{array}$} \\
\hline 2 & \multicolumn{2}{|c|}{$\begin{array}{l}\text { Dioscorea hispida } \\
\text { Dennst. (D) } \\
\text { Vr. Name: Noolana hambu }\end{array}$} & Dioscoreaceae & Tubers & 15 & \\
\hline 3 & \multicolumn{2}{|c|}{$\begin{array}{l}\text { Glycosmis mauritiana (Lam) } \\
\text { Tanaka. (G) } \\
\text { Vr. Name: Orrange berry }\end{array}$} & Rutaceae & leaves & 25 & \\
\hline 4 & \multicolumn{2}{|c|}{$\begin{array}{ll}\text { Nothapodytes } & \text { nimoniana, } \\
\text { Blume. (N) } & \\
\text { Vr. Name: } & \\
\text { Durvasane mara } & \\
\end{array}$} & Icacinaceae & Leaves & 25 & \\
\hline 5 & \multicolumn{2}{|c|}{$\begin{array}{l}\text { Rauwolfia densiflora Benth \& } \\
\text { Hook. R) } \\
\text { Vr. Name: Snake root }\end{array}$} & Apocynaceae & Leaves & 15 & \\
\hline \multicolumn{7}{|c|}{ AGE, DURATION AND MODE OF TREATMENTS OF TRIBAL MEDICINE FORMULATION } \\
\hline \multicolumn{2}{|c|}{ Paste of HMF } & \multicolumn{2}{|c|}{$\begin{array}{l}\text { It is applied on affected part of the } \\
\text { wound, skin cut, infected region due to } \\
\text { tumour formation with few drops of } \\
\text { Lime juice as external application. }\end{array}$} & \multicolumn{3}{|c|}{$\begin{array}{l}\text { Duration: } \\
\text { Apply paste at wound area \& cover with a thin } \\
\text { cloth 4times/week }\end{array}$} \\
\hline \multicolumn{2}{|c|}{$\begin{array}{l}\text { Decoction of } \\
\text { HMF }\end{array}$} & \multicolumn{2}{|c|}{$\begin{array}{l}\text { Ground \& juice boiled with warm } \\
\text { water \& swallowed internally for } \\
\text { tumour related problems. Decoction } \\
\text { with warm water/ goat milk for } \\
\text { inflammation, skin destructions and } \\
\text { related ailments }\end{array}$} & \multicolumn{3}{|c|}{$\begin{array}{l}\text { Duration: } \\
\text { One tsp two times a day for } 7 \text { days. }\end{array}$} \\
\hline
\end{tabular}

*HMF obtained from TMM was validated by Authorized Ayurvedic Practitioner

Table. 2: Phyto-chemical analysis in different extracts of HMF drug

\begin{tabular}{|l|l|l|l|l|l|l|l|l|l|l|l|}
\hline $\begin{array}{l}\text { SL. } \\
\text { No. }\end{array}$ & Phytochemicals & $\mathrm{A}$ & $\mathrm{B}$ & $\mathrm{C}$ & $\mathrm{D}$ & $\mathrm{E}$ & $\mathrm{F}$ & $\mathrm{G}$ & $\mathrm{H}$ & $\mathrm{I}$ & $\mathrm{J}$ \\
\hline 1. & Carbohydrate & + & + & + & - & - & + & + & - & + & + \\
\hline 2. & Proteins & + & + & - & + & - & + & + & + & - & + \\
\hline 3. & Alkoloids & + & + & + & + & + & - & - & - & + & + \\
\hline 4. & Flavonoids & + & + & + & - & - & - & - & + & - & - \\
\hline 5. & Terpenoids & + & + & + & + & - & - & - & - & - & + \\
\hline 6. & Tannins & + & + & - & + & - & - & - & - & - & + \\
\hline 7. & Phenol & - & + & - & - & - & - & - & - & - & - \\
\hline 8. & Saponin & + & + & - & - & - & - & - & - & - & + \\
\hline 9. & Oils\& fats & + & + & - & - & - & - & - & - & - & + \\
\hline
\end{tabular}

A-Cold water, B-Hot water, C-Ethanol, D-Methanol, E-Acetone, F-Chloroform, G-petroleum ether, $\mathrm{H}$-Ethyl acetate, I-Hexane, $\mathrm{J}-\mathrm{NaCl}$ 
Table 3. Antioxidant activity (ABTS) free radical scavenging activity in HMF drug

\begin{tabular}{|l|l|l|}
\hline $\begin{array}{l}\text { Test } \\
\text { Variables }\end{array}$ & Plant Extrant & IC50 $\boldsymbol{\mu g} / \mathbf{m l}$ \\
\hline Sample & HMF drug extract & $7 \pm 0.74$ \\
\hline Référence & Gallic acid & $1.72 \pm 0.03$ \\
\hline
\end{tabular}

Table 4. Showing column fractions of Crude drug in Column Chromatography

\begin{tabular}{|l|l|l|l|}
\hline $\begin{array}{l}\text { Column eluents } \\
\text { of ethanol extract }\end{array}$ & $\begin{array}{l}\text { Distance moved by } \\
\text { the compound(cm) }\end{array}$ & $\begin{array}{l}\text { Distance moved by } \\
\text { the solvent }(\mathbf{c m})\end{array}$ & $\begin{array}{l}\text { Retention } \\
\text { factor(cm) }\end{array}$ \\
\hline Crude sample & 14.7 & 19.5 & 0.754 \\
\hline Fraction 1 & 16.1 & 19.5 & 0.826 \\
\hline Fraction 2 & 16.1 & 19.5 & 0.826 \\
\hline Fraction 3 & 16.2 & 19.5 & 0.83 \\
\hline Fraction 4 & 15.8 & 19.5 & 0.81 \\
\hline
\end{tabular}

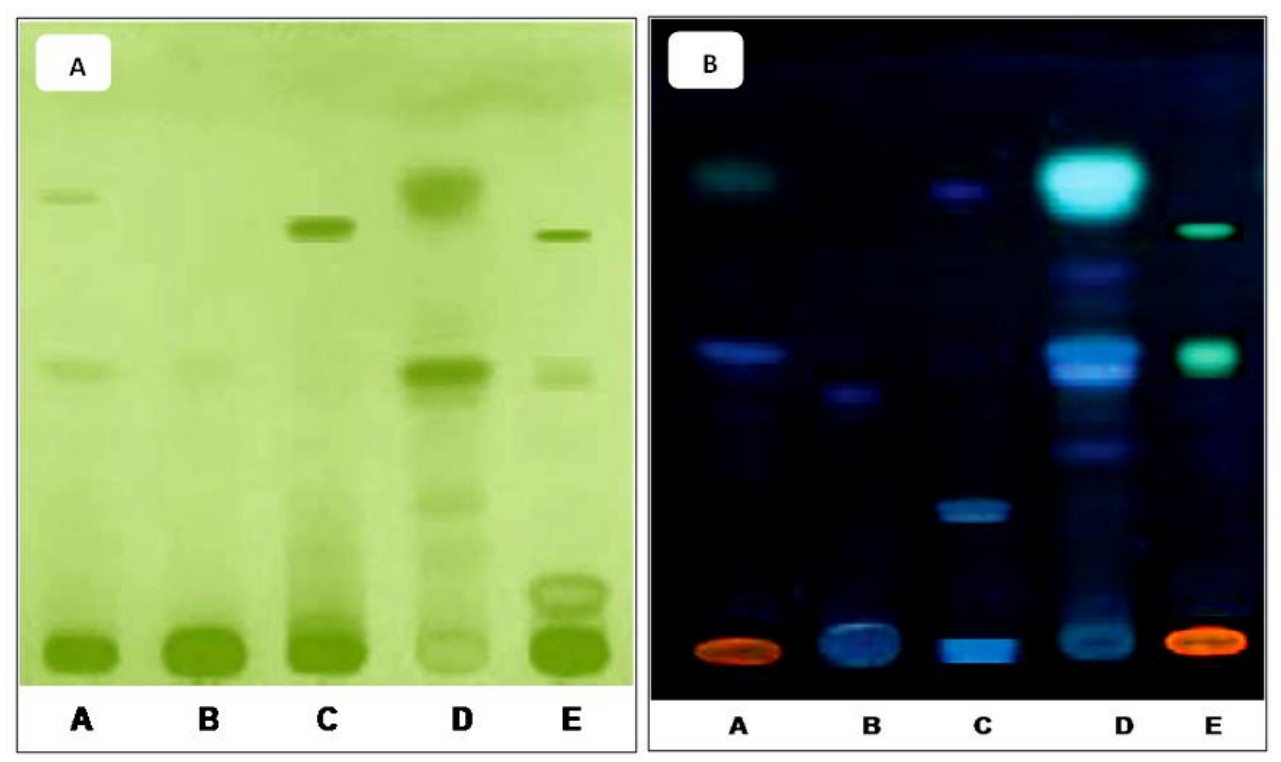

Fig. 2A \& B. The TLC chromatograms of the individual components of HMF drug extracts

A: A. serpyllifolia, B: D.hispida; C: G. mauritiana; D: N.nimmoniana; E: R. densiflora Stationary phase: Silica gel GF254; Mobile phase: toluene: chloroform: ethanol = 5: 5:2) $\{($ Observed under ultra violet light $254 \mathrm{~nm}$ (A) and 366nm (B) \}

\section{Evaluation of Anticancer activity}

Table 5. Showing Tryphan Blue assay values in different concentrations of HMF drug

\begin{tabular}{|l|l|l|}
\hline SL. No & Concentration & \% Cell Death \\
\hline $\mathbf{1}$ & Media & 8.39 \\
\hline $\mathbf{2}$ & Vehicle & 17.46 \\
\hline $\mathbf{3}$ & $10 \%$ & 48.82 \\
\hline $\mathbf{4}$ & $6 \%$ & 41.72 \\
\hline $\mathbf{5}$ & $5 \%$ & 39.6 \\
\hline $\mathbf{6}$ & $4 \%$ & 30.26 \\
\hline $\mathbf{7}$ & $3 \%$ & 26.6 \\
\hline
\end{tabular}




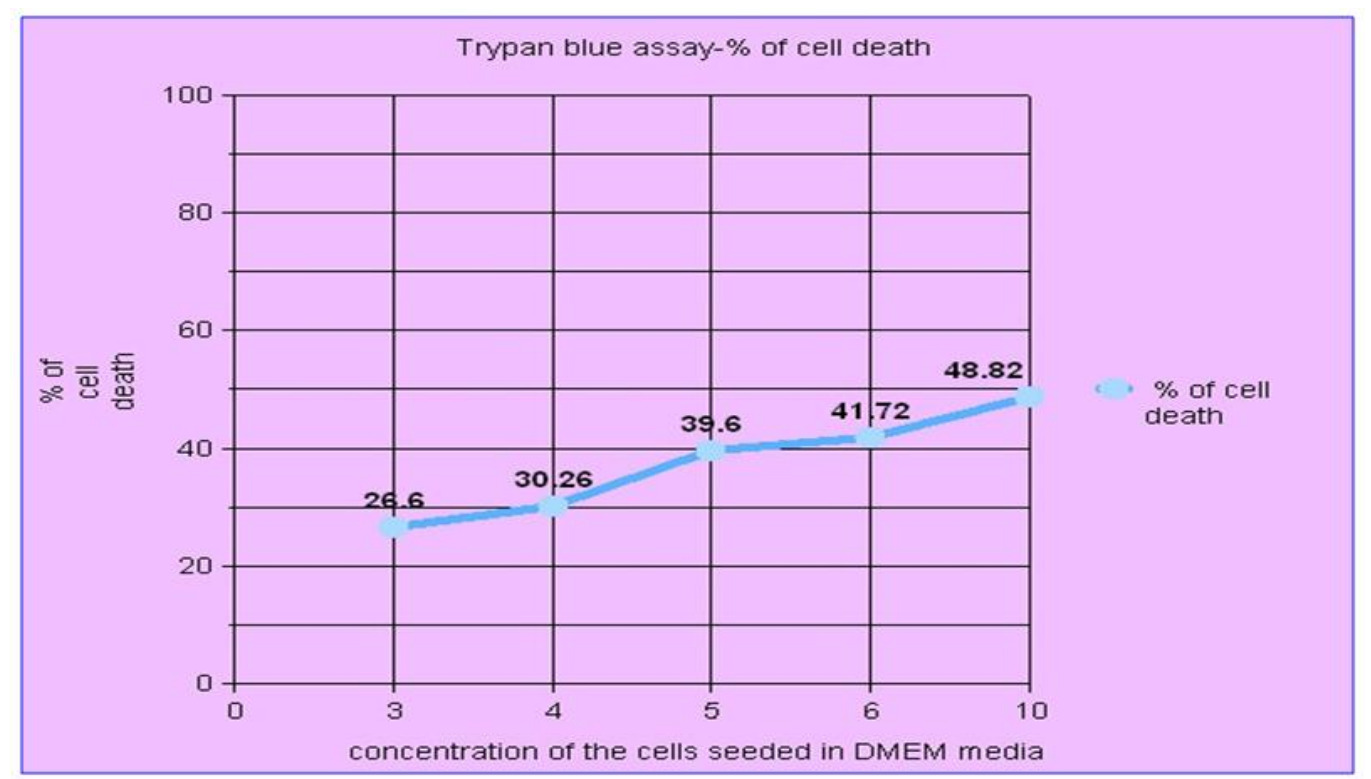

Fig. 3. Showing the $\%$ of cell death after Trypan blue assay in different concentrations of HMF drug

Table 6. Showing $\mathrm{IC}_{50}$ value of cells from MTT assay after $24 \mathrm{hrs}$ of incubation in different concentrations of HMF drug.

\begin{tabular}{|l|l|l|}
\hline $\begin{array}{l}\text { Concentration of crude } \\
\text { ethanol extract }\end{array}$ & \% viability of cells & IC50 $\mu \mathrm{g} / \mathrm{ml}$ \\
\hline media & & \\
\hline vehicle & 32.12 & \\
\hline 10 & 47.22 & \\
\hline 9 & 42.00 & \\
\cline { 1 - 2 } & 33.82 & \multirow{2}{*}{5.45} \\
\hline 7 & 24.84 & \\
\hline 6 & 11.11 & \\
\hline 5 & 20.42 & \\
\hline 4 & 26.96 & \\
\hline 3 & 38.72 & \\
\hline
\end{tabular}

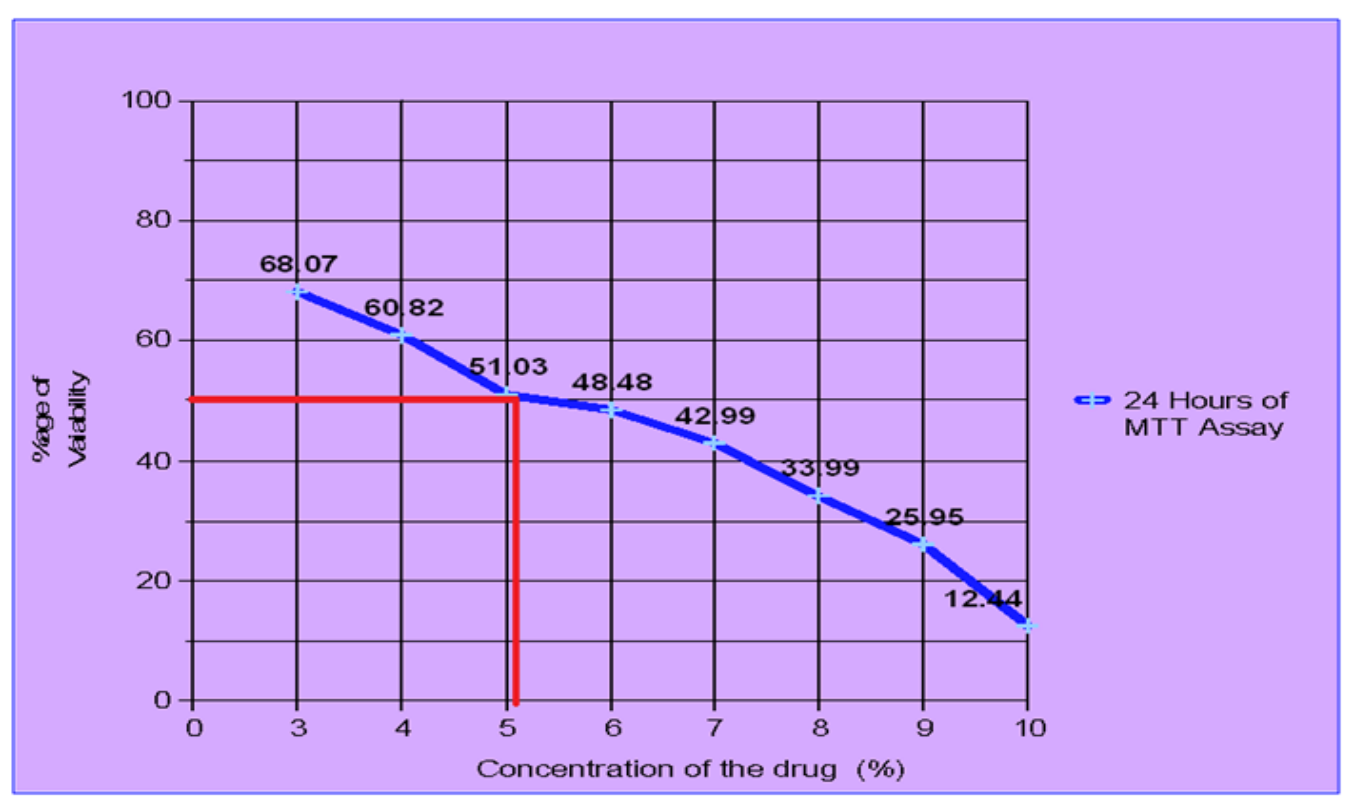

Fig. 4. Showing the $\mathrm{IC}_{50}$ value of MTT assay after $24 \mathrm{hrs}$ of incubation in different concentrations of HMF drug. 
Table 7. Table showing $\mathrm{IC}_{50}$ value of cells from MTT assay after $48 \mathrm{hrs}$ of incubation in different concentrations of HMF drug

\begin{tabular}{|l|l|l|}
\hline $\begin{array}{l}\text { Concentration of crude ethanol } \\
\text { extract }\end{array}$ & $\%$ Viability of cells & \multirow{2}{*}{ IC50 $\mu \mathrm{g} / \mathrm{ml}$} \\
\hline media & \multicolumn{1}{|}{} \\
\hline Vehicle & 96.69 & \multirow{3}{*}{5.1} \\
\hline 10 & 47.52 & \\
\hline 9 & 24.75 & \\
\hline 8 & 11.22 & \\
\hline 7 & 3.96 & \\
\hline 6 & 13.20 & \\
\hline 5 & 17.49 & \\
\hline 4 & 33.99 & \\
\hline 3 & 46.20 & \\
\hline
\end{tabular}

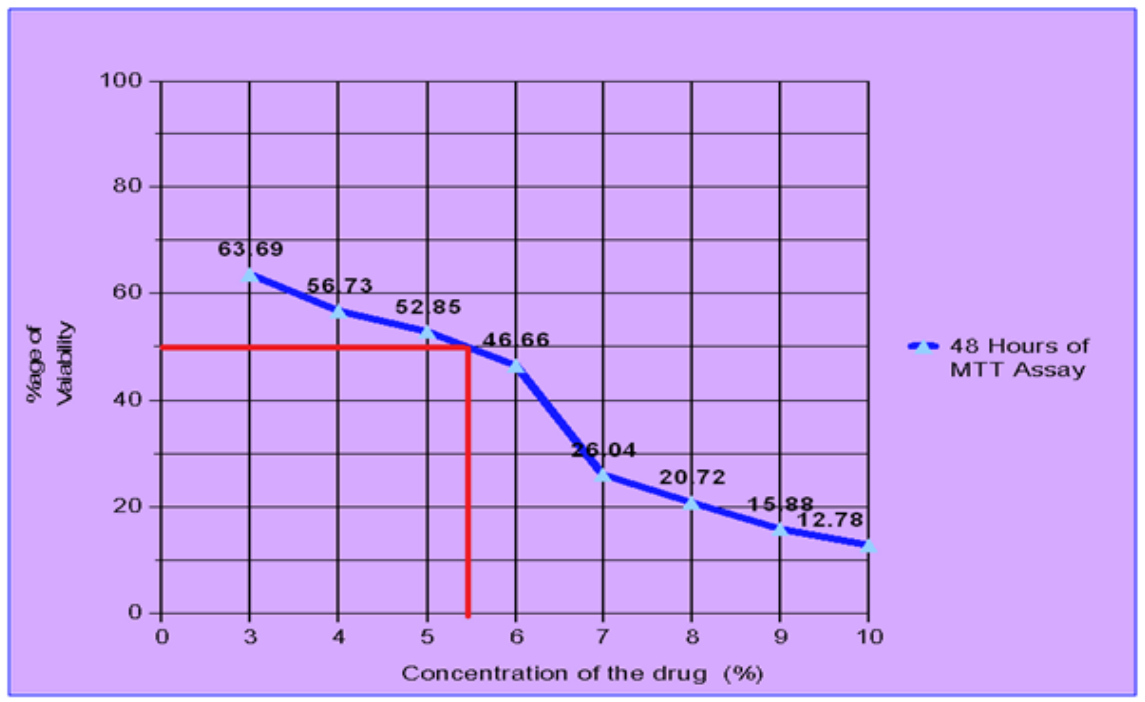

Fig. 5. Showing the $\mathrm{IC}_{50}$ value of MTT assay after $48 \mathrm{hrs}$ of incubation in different concentrations of HMF drug

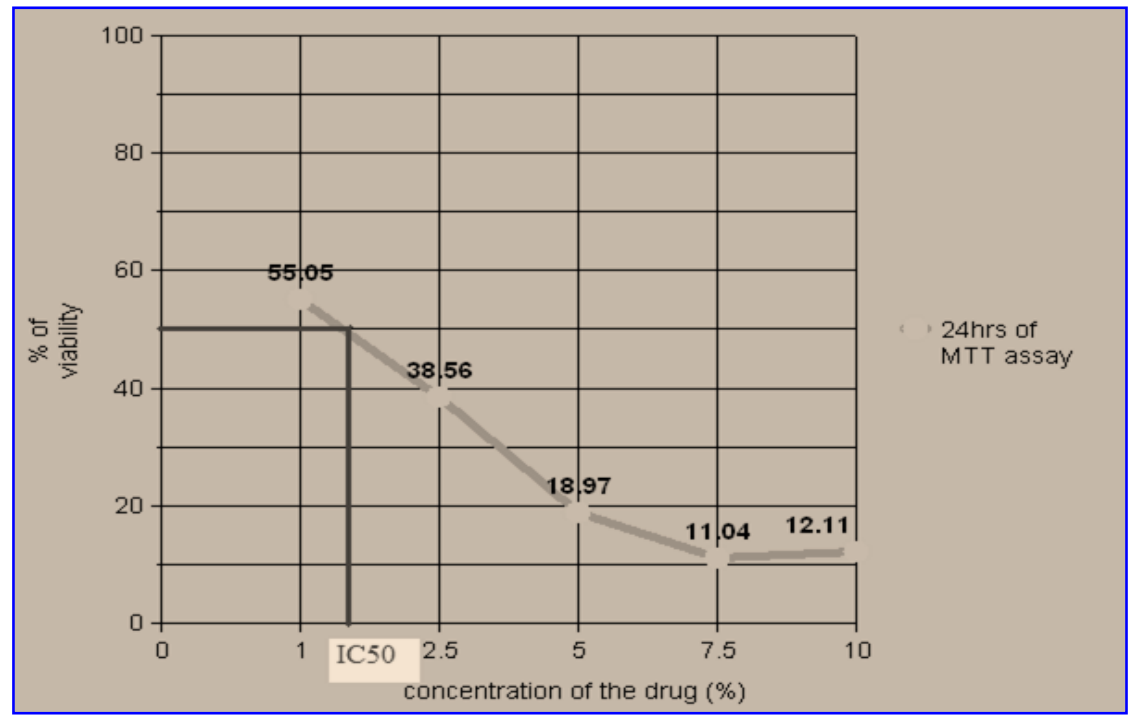

Fig. 6. MTT assay in different concentrations of aqueous extract of HMF drug 


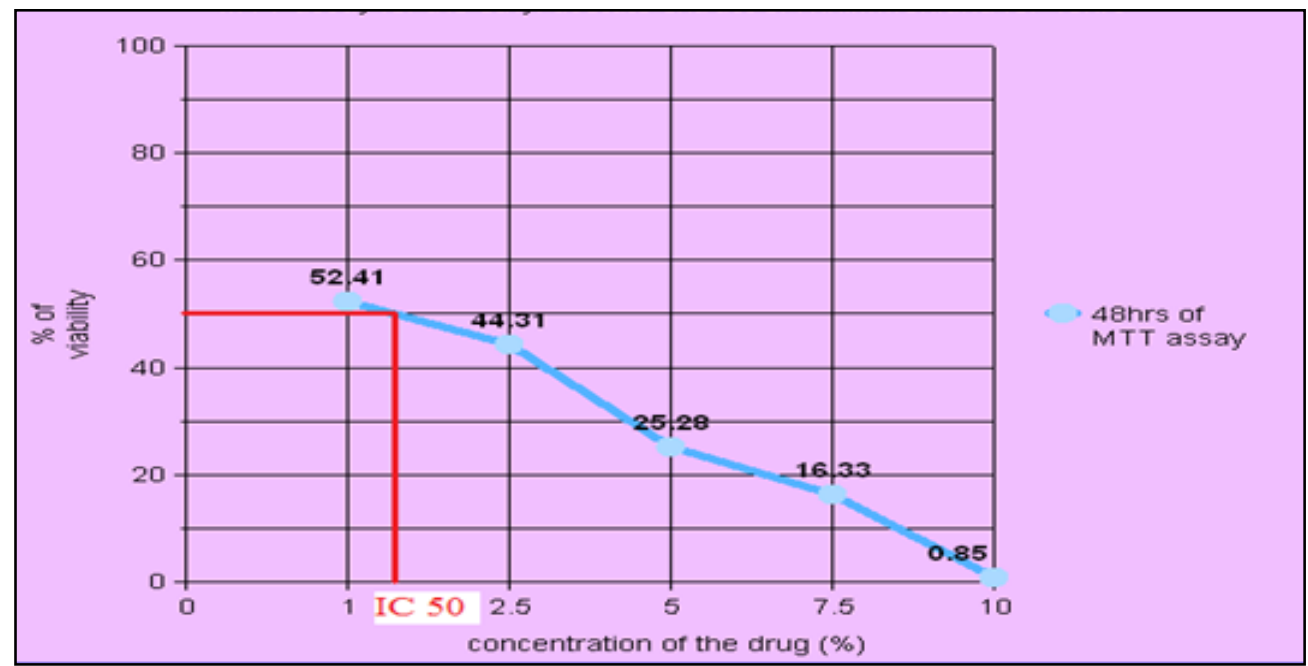

Fig. 7. MTT assay in different concentrations of HMF drug for $24 \mathrm{hrs}$

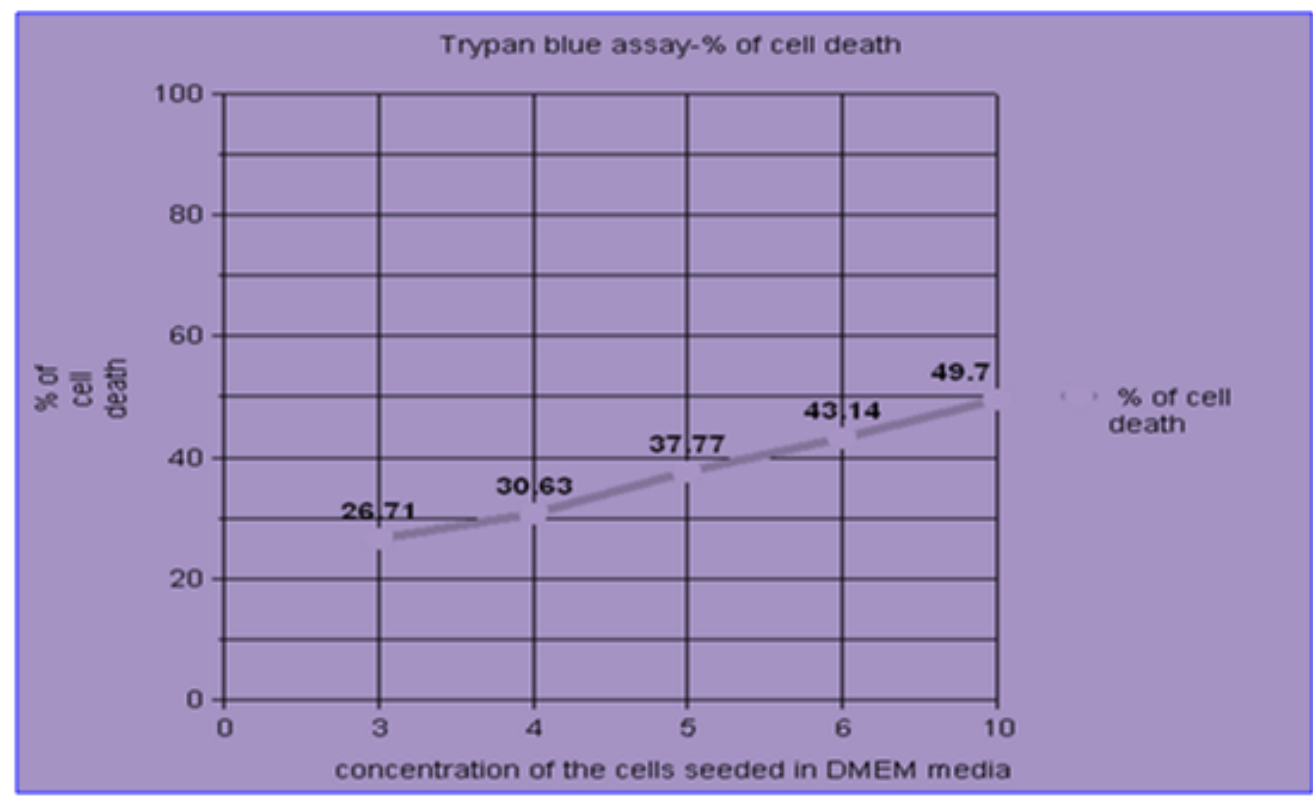

Fig. 8. Trypan Blue assay in different concentrations of HMF drug for $48 \mathrm{hrs}$ Anticancer activity from different (Crude) concentrations of HMF drug
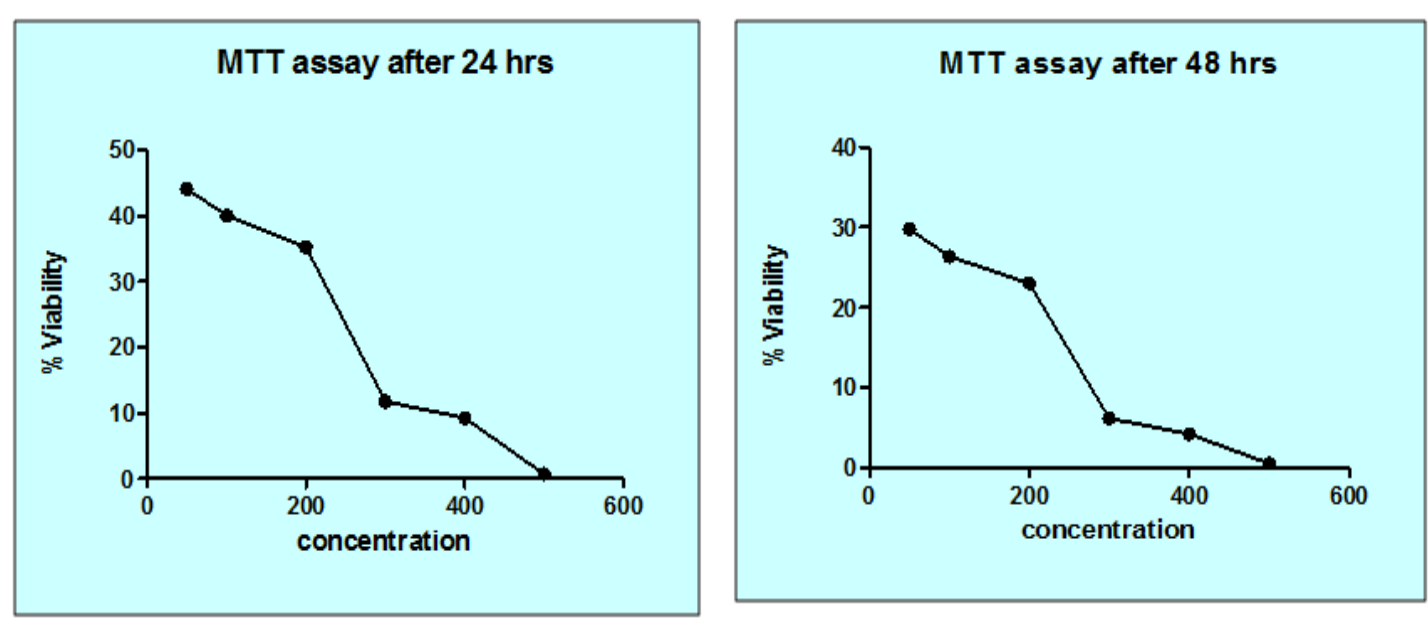

Fig. 9A \& B. MTT Assay in different concentrations HMF drug (24 and 48 hrs) 


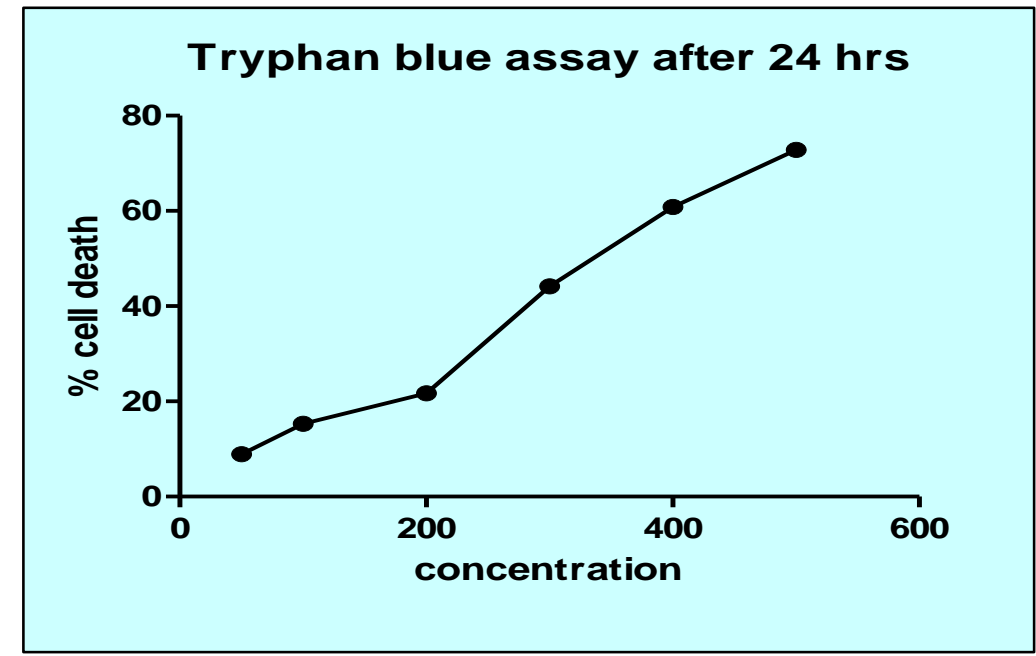

Fig.10. Trypan blue test in different concentrations HMF drug for 24 hours

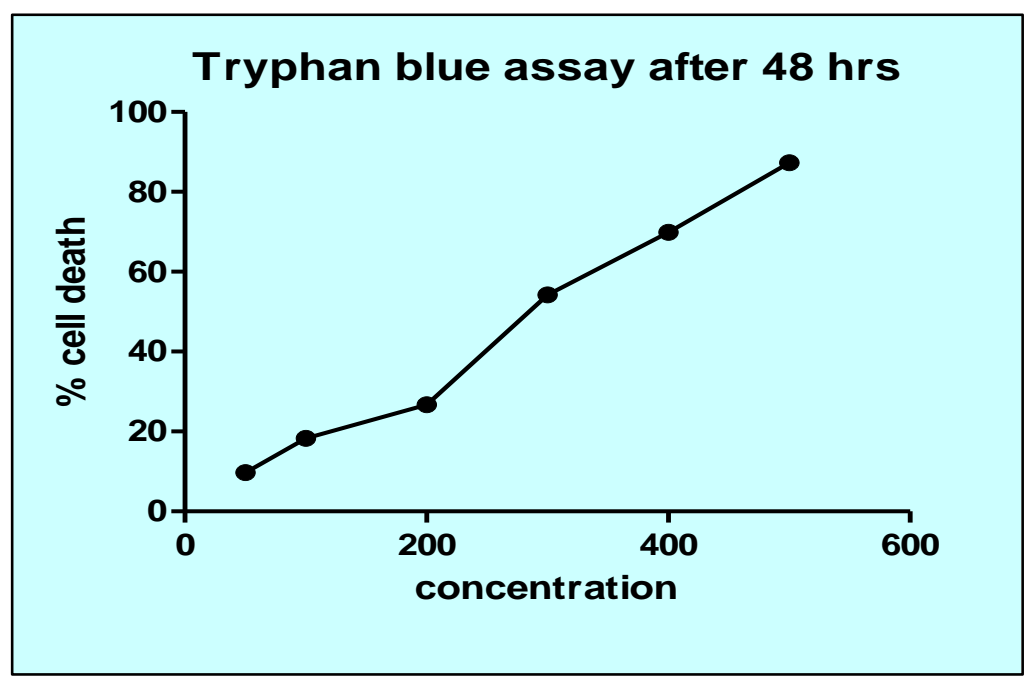

Fig. 11. Trypan blue test in different concentrations HMF drug for 48 hours

Apoptosis of HeLa cells after the action of HMF drug extract

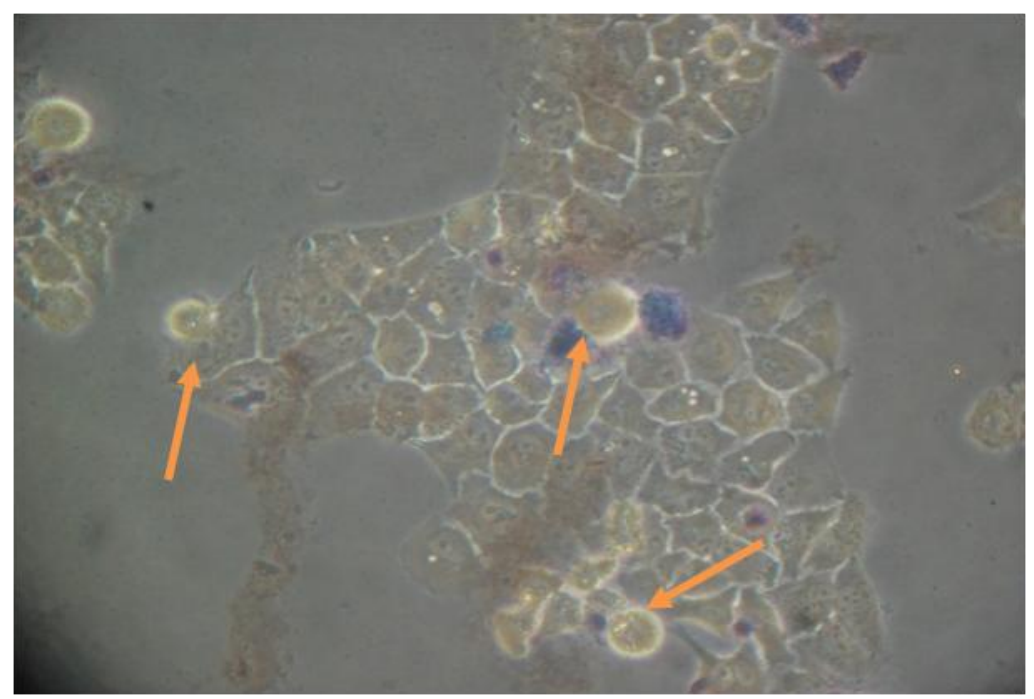

Fig. 12. Trypan Blue Assay -Lowest concentration: 20 to $30 \%$ Cell death 


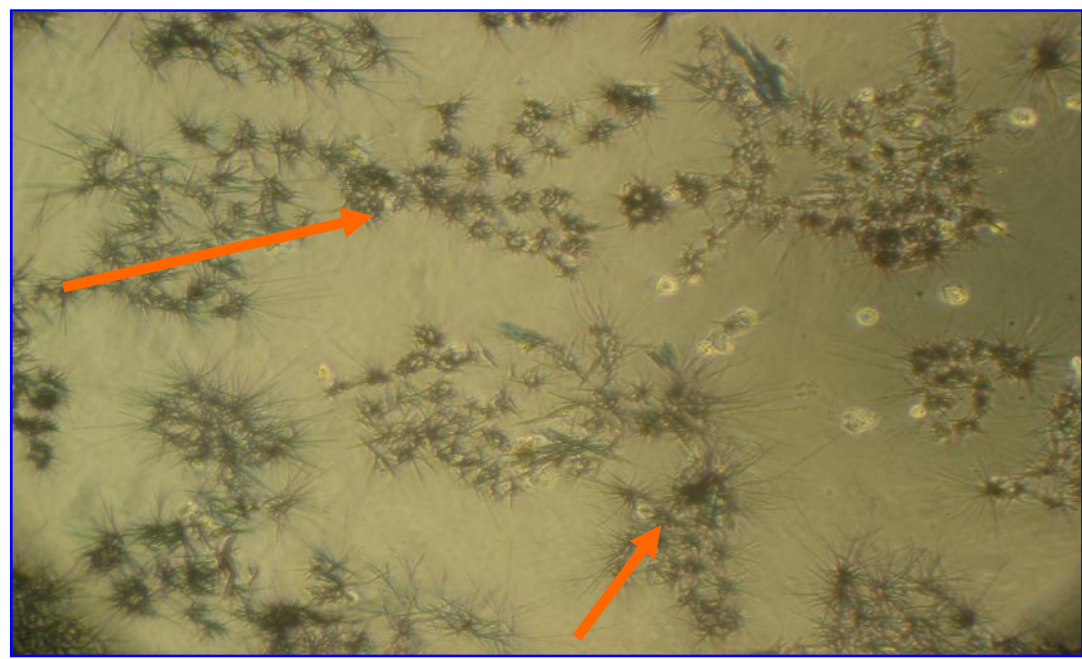

Fig. 13. MTT Assay showing crystallization of the cell matrix in 48 hours

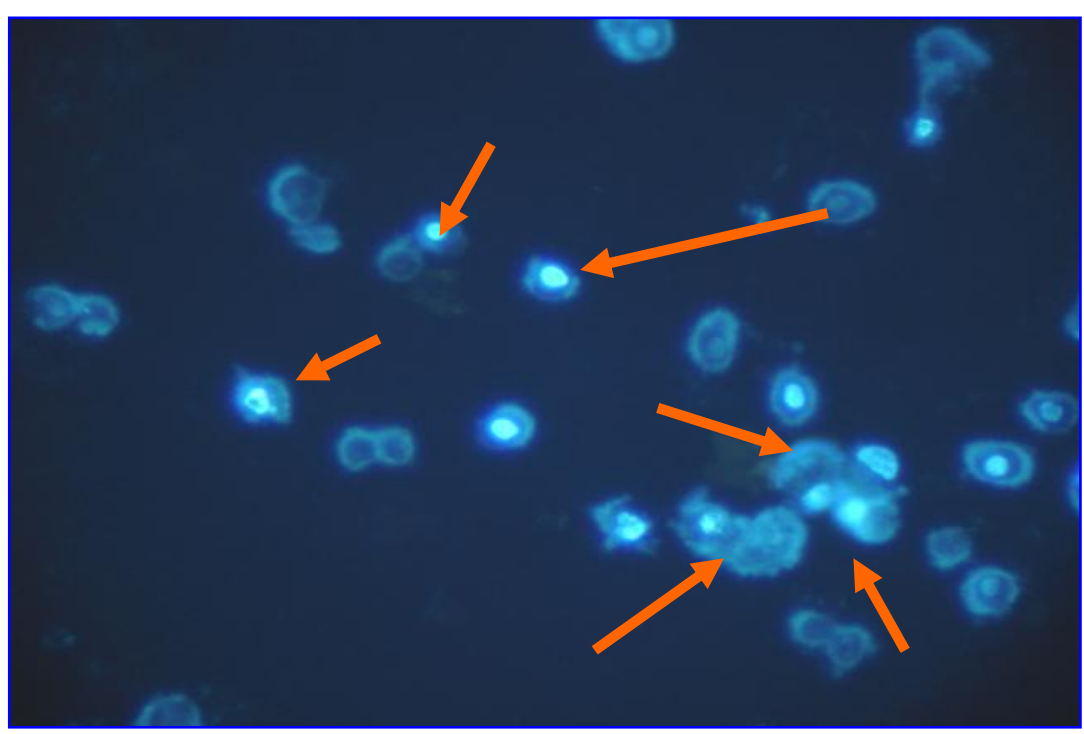

Fig. 14. Hoechst's Assay - High Concentration: 100\% Cell death Apoptosis of MCF-7 Cells, after the action of HMF drug extract

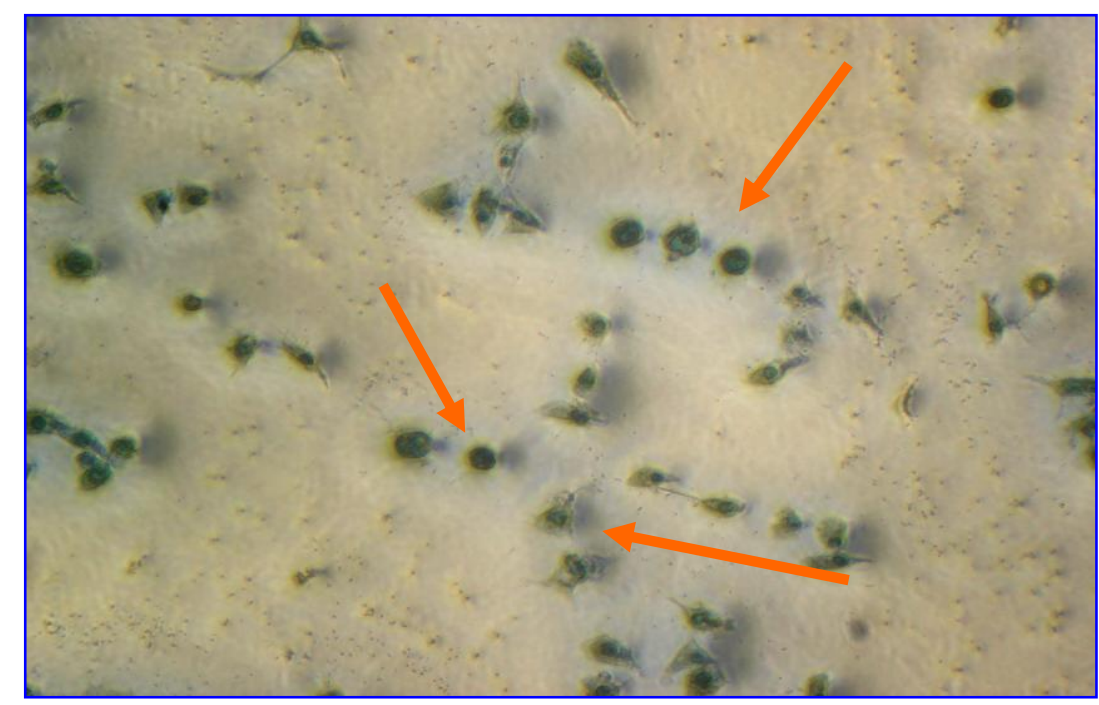

Fig. 15. MTT Assay-Crystal formation (24hrs) in Ethno-medicinal plants Formulation HMF drug 


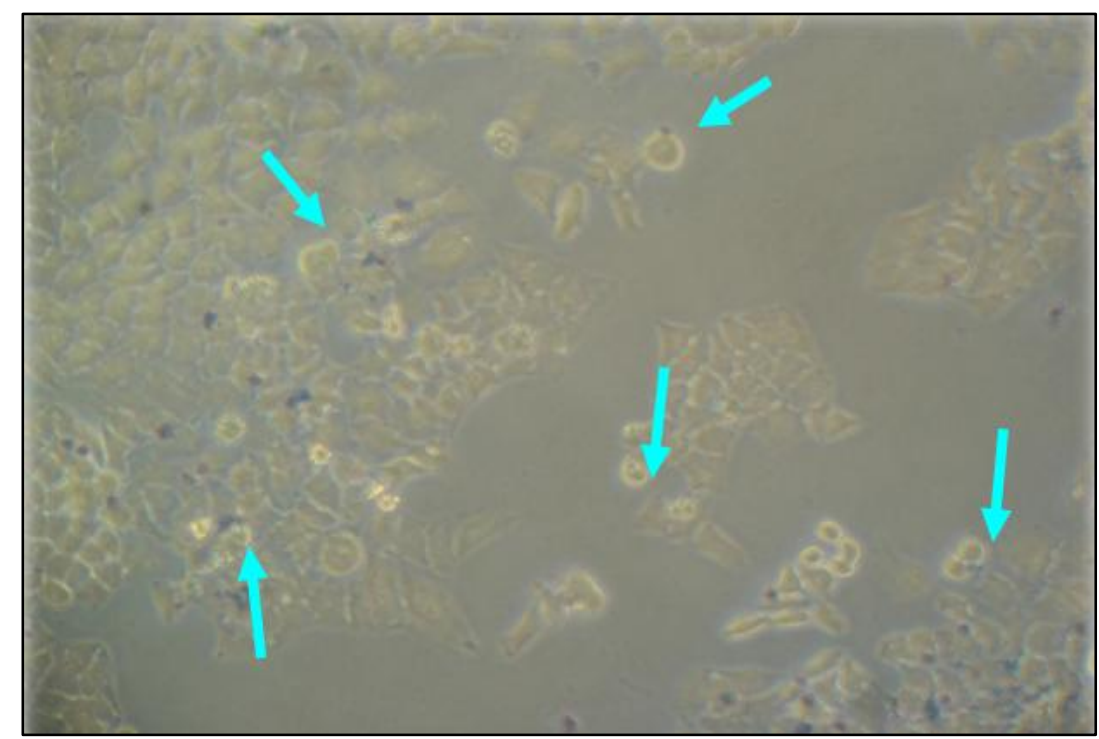

Fig. 16. Trypan Blue Assay-Lowest concentration: 40-50\% Cell Death (24hrs) in Ethno-medicinal plants formulation HMF drug

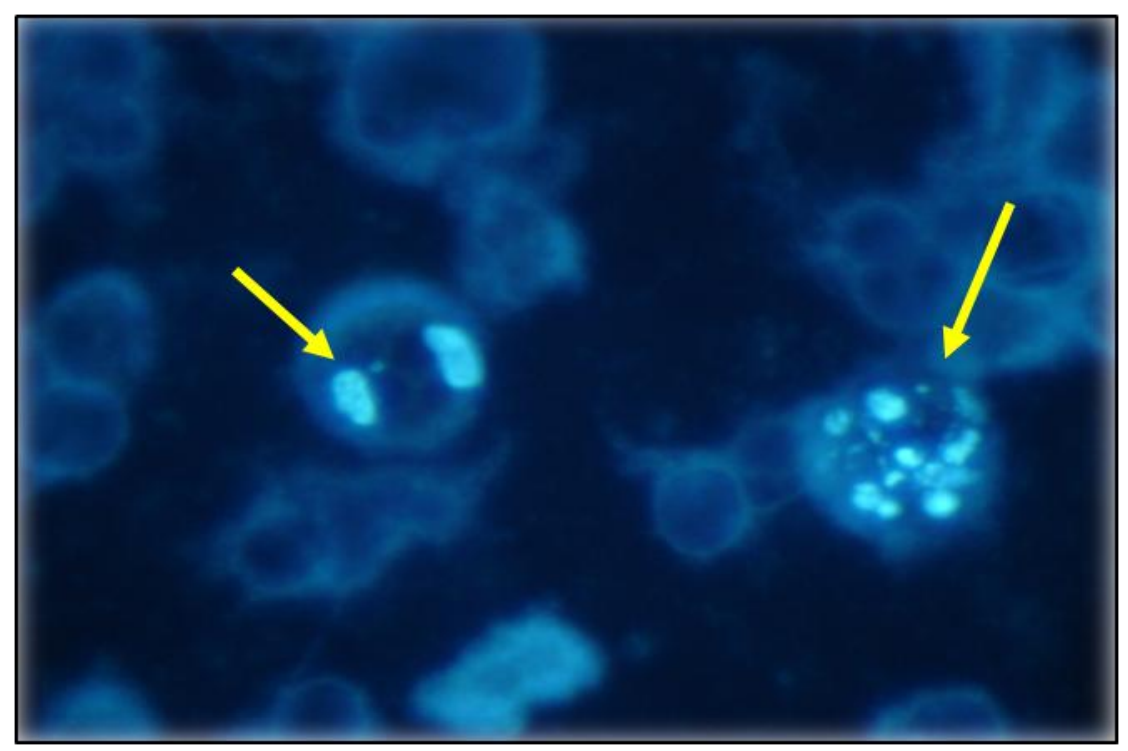

Fig. 17. Hoechst staining: To visualize the chromosomes after the action of the test sample HMF drug 